\title{
THE DISTRIBUTION OF IRON IN THE WATERS OF THE WESTERN ENGLISH CHANNEL
}

\author{
By L. H. N. Cooper, D.Sc., F.R.I.C.
}

Chemist at the Plymouth Laboratory

(Text-figs. I-2)

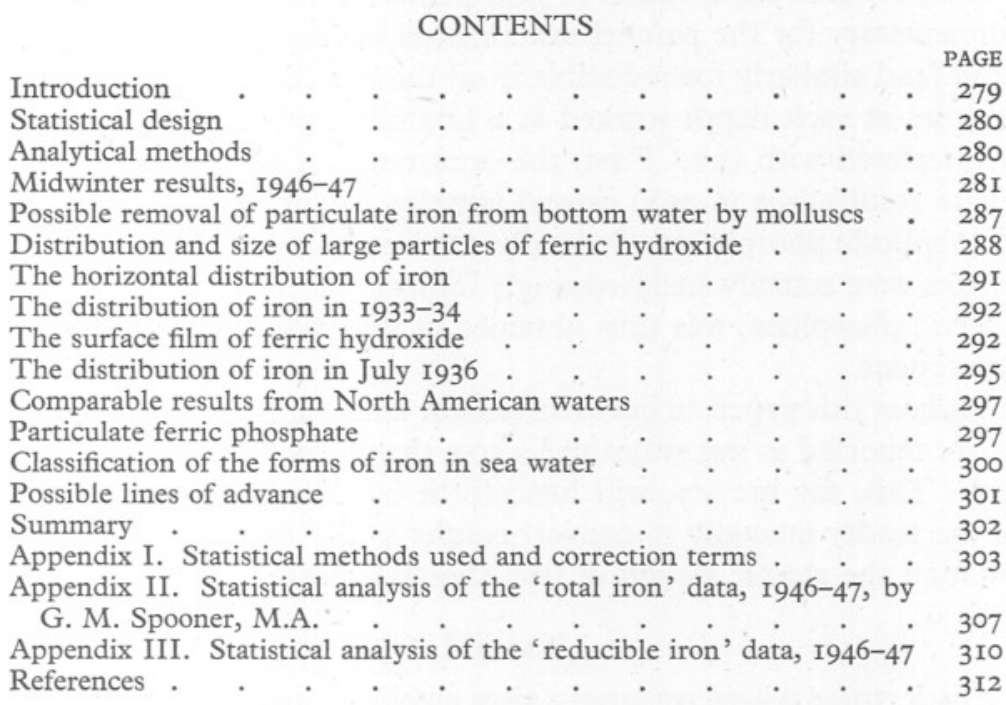

INTRODUCTION

Iron is essential for all plants and animals, but only a small supply is available in sea water. Since most compounds of iron are very sparingly soluble in neutral or alkaline solution, their distribution in the sea may follow a very different pattern from that of phosphate and nitrate. Earlier it had been shown (Cooper, 1935; Thompson \& Bremner, 1935 $b$; Rakestraw, Mahncke \& Beach, 1936) that the distribution of iron in the sea was very erratic, even under conditions when vertical mixing would be expected to be thorough, so that much of it must be particulate and subject to random distribution (cf. Harvey, I945, pp. 34, I36). The fluctuations in the iron content of small replicate samples of sea water may be large, so that either very large volumes of water must be examined, as in net methods for capturing plankton, or chemical analyses on small volumes of water must be submitted to statistical scrutiny. The precision of the analytical method has consequently been first assessed before proceeding to examine samples of water collected in the western 
English Channel at the time of the midwinter maximum of dissolved inorganic phosphate. This approach has yielded considerable information as to the nature and distribution of iron in the sea and of the size and numbers of particles containing iron. Evidence has also accrued for the concentration of iron in the surface film and in the layers of water next the bottom. In certain restricted areas the bottom concentration of iron appears to be removed by suspension feeding animals. On occasion particulate ferric phosphate was present.

\section{Statistical Design}

The known random distribution of iron demanded statistical methods which were unnecessary for the parallel examination of phosphate and silicate. For total iron (and similarly for reducible iron) the plan had been to analyse three sub-samples at each depth worked at a limited number of stations, but two events interfered with this. First, the occurrence of several 'untrustworthy' phosphate results (see p. 298) caused samples meant for iron analyses to be used for replicate phosphates. Secondly, other samples brought in for duplicate phosphates were actually analysed singly for iron: more information, especially about ferric phosphate, was thus obtained at the expense of the symmetry of the experiment.

Throughout this paper, to have convenient units for the analyses of variance, results are reported as mg.-atom $/ \mathrm{m}^{3} \times 100$, that is the unit of measurement is I in $10^{11}$. This, for brevity, will henceforth be called a 'unit'. Table I will enable the reader mentally to convert results to his own favoured units. For computation the atomic weight of iron should however be taken as 55.84 .

\section{TABLE I}

Each vertical column represents a given quantity of iron in different units

\begin{tabular}{|c|c|c|c|c|}
\hline mg.-atom $/ \mathrm{m}^{3} \times 100 \mathrm{Fe}$ & IOO & I & $\mathrm{I} \cdot 8$ & $I \cdot 25$ \\
\hline $\begin{array}{l}\text { mg.-atom } / \mathrm{m}^{3} \mathrm{Fe} \\
\mu \mathrm{g} \text {.-atom } / 1 . \mathrm{Fe}\end{array}$ & I & O.OI & 0.0I8 & 0.0125 \\
\hline $\begin{array}{l}\mathrm{mg} . / \mathrm{m}^{3} \mathrm{Fe} \\
\mu \mathrm{g} . / \mathrm{Fe}\end{array}$ & 56 & 0.56 & I & 0.7 \\
\hline $\begin{array}{l}\mathrm{mg} . / \mathrm{m}^{3} \mathrm{Fe}_{2} \mathrm{O}_{3} \\
\mu \mathrm{g} . / 1 . \mathrm{Fe}_{2} \mathrm{O}_{3}\end{array}$ & 80 & 0.80 & $I \cdot 4$ & I \\
\hline
\end{tabular}

Although, to comply with conventional chemical usage, statistical means and standard deviations are reported to no more significant figures than would be given for single analyses, all calculations have been made to four or five places by machine.

\section{ANALYTiCAl Methods}

In 1936 the reagent, 2:2'-dipyridyl, was used exactly as before (Cooper, I935, pp. 420-24). In 1946-47 a number of small but important alterations were made.

Reducible iron. Into a $250 \mathrm{ml}$. flask $\mathrm{I} 50 \mathrm{ml}$. of sea water from a very wellshaken sample bottle were introduced and treated with $0.30 \mathrm{ml} .4 \mathrm{~N}-\mathrm{HCl}$ and 
$\mathrm{I} .5 \mathrm{ml}$. of freshly prepared 10\% sodium sulphite to give a solution having a $\mathrm{pH}$ around $2 \cdot 8$. After at least 4 and preferably $\mathrm{I} 8 \mathrm{hr} .0 .4 \mathrm{ml} .4 \mathrm{~N}$-ammonium acetate and $\mathrm{I} .5 \mathrm{ml} .0 .4 \%$ dipyridyl in $0.2 \mathrm{~N}-\mathrm{HCl}$ were added to give a $\mathrm{pH}$ around 5.0. After a further $4 \mathrm{hr}$. the depth of colour of the sample in a $25 \mathrm{~cm}$. absorption tube was determined with the Pulfrich photometer using the bluegreen $\mathrm{S}_{5} 0$ spectral filter.

As a result of Buch's (1942) careful examination of the method further modifications may be needed but at the time of the cruise a translation of his Swedish text was not available. This paper will be considered at a later date in connexion with the chemistry of ferrous-tris-dipyridyl.

Total iron sensu strictu. Strictly total iron can be determined only if the water and everything in it is digested with sulphuric acid to fuming as by Thompson \& Bremner (1935a). This procedure is very time consuming and would have been impossible in a temporary laboratory such as that used at Newlyn for the present investigation.

'Total' iron as determined. The original method was modified precisely as that for reducible iron. Compounds of iron were broken down by boiling with acidified bromine water. This method sets free only $4 \mathrm{I} \%$ of the iron in a solution of Waksman's ferrolignoprotein in sea water, whilst the method for reducible iron will liberate $20-25 \%$. In sea water, therefore, there may well be organic compounds which are resistant to this treatment and terrigeneous clay and mineral particles would certainly be so. None the less, the method measures a definable quantity, is quick, and with occasional recourse to a service gas-mask may be used in a laboratory not equipped with a fume chamber.

The evaluation of the correction terms and of random analytical errors is given in Appendix I.

\section{MIDWINTER ResUlTS, 1946-47}

A temporary analytical laboratory was set up at Newlyn, the most westerly fishing port in Cornwall, and occupied between I and 28 January 1947. During that period the Marine Biological Association's research vessel Sabella made her base there with Mr P. G. Corbin as scientific officer in charge of work at sea. The data on the distribution of salinity, temperature, phosphate, silicate and zooplankton will be published separately. Fig. I shows the position of the stations worked for iron samples; fuller details will be presented in the paper dealing with phosphate. A preliminary cruise was also made on 4 and 5 December 1946.

The results are set out in detail in Table II. Triplicate analyses did not agree. Moreover, the distribution of iron at the bottom was markedly different from that in the water between the surface and $50 \mathrm{~m}$. The dispersion of all results for reducible and for total iron may be seen from Fig. 2 in which all separate analyses have been grouped in arguments of $5 \mathrm{mg}$.-atom $/ \mathrm{m} .{ }^{3} \mathrm{Fe} \times 100$ or 'units'. The distribution of analyses of inorganic phosphate constructed 
with the same argument was utterly different. The relatively few analyses for bottom water showed a very wide spread.

Much of the iron must be distributed very differently from inorganic phosphate and nitrate. The latter, except for a little ferric phosphate (see below), are truly dissolved in the water, are vertically uniformly distributed under uniform isothermal, isohaline conditions and usually show complete uniformity within a small sample.

At station $\mathrm{A}_{3}$ ( = International Hydrographic Station E2) on 7 January, the weather was very heavy, no nets could be worked, the sounding of I IO m. was

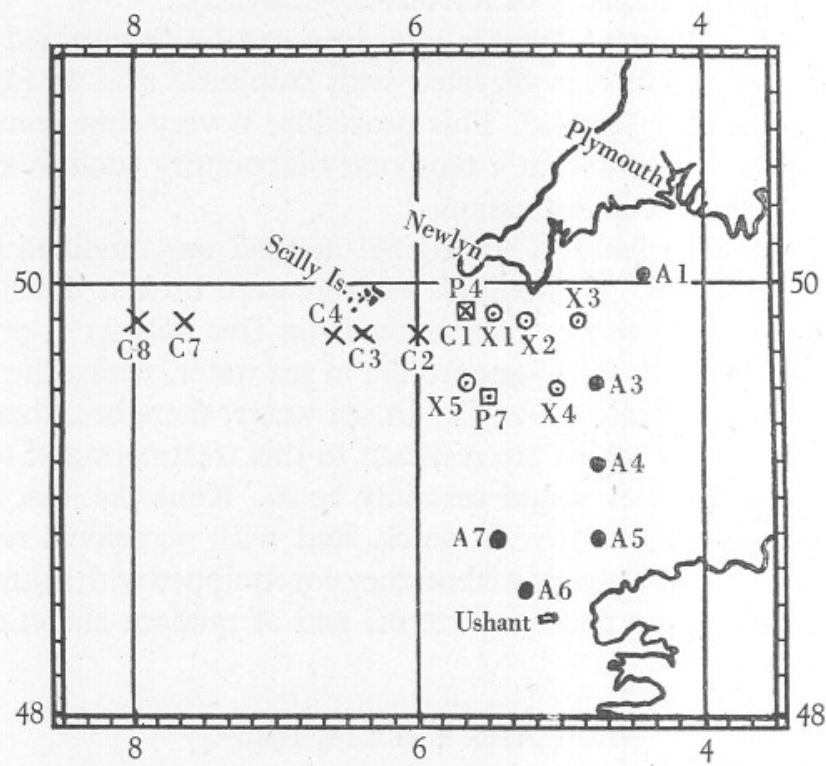

Fig. I. Station positions. Cruise P, 4-5 December 1946. Cruise A, 6-7 January 1947. Cruise C, I7-18 January 1947. Cruise X, 21-22 January 1947. Equivalent international

(E) stations: $\mathrm{E}_{\mathrm{I}}=\mathrm{A}$ I, $\mathrm{E}_{2}=\mathrm{A}_{3}, \mathrm{E}_{3}=\mathrm{A} 6, \mathrm{E}_{7}=\mathrm{P}_{4}=\mathrm{Cr}_{1}, \mathrm{E}_{25}=\mathrm{C}_{4}$.

at least $15 \mathrm{~m}$. too great and the angle on the warp when sounding and when sampling at 50 and $80 \mathrm{~m}$. nominal depth was estimated at $35-40^{\circ}$. Whether this weather was the cause or not, the results were highly anomalous, and have had to be omitted from the statistical examination of all samples taken at standard depths, presented in detail in Appendices II and III and summarized in Table III.

Within the upper layers, analyses of both total and reducible iron at different depths $(5,25$ and $50 \mathrm{~m}$.) show no significant variation either in mean values or in the variation as shown between analyses. The whole of the variability of the total iron appears to be due to the reducible iron component. The difference of 6 units may be attributed to a dispersed unreducible fraction with a standard deviation not differing significantly from zero. There is present therefore a 
small dispersed fraction detectable only when the water has first been oxidized with bromine water. It is most probably in organic combination and under the conditions prevailing in January 1947 must have been present in the bottom water in like amount. The analytical data require only that this unreducible fraction shall be well dispersed in the water. It does not necessarily require it to be truly dissolved.

\section{Table II. Total and Reducible Iron in the English Channel, December I946 TO FEBRUARY I947 AS MG.-ATOM/IOO M. ${ }^{3}$ FE, REFERRED TO IN THE TeXt as 'Units'. Volume ANALYSED THROUGHout WAS I5O ML.*}

Station and sounding (m.)

$\mathrm{P}_{4}\left(=\mathrm{E}_{7}\right)$
$(76 \mathrm{~m}$.

P7. (I04 m.)

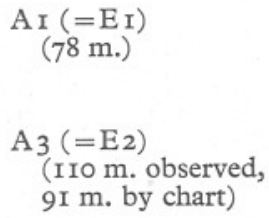

Depth

(m.)

Reducible iron Cruise P, 4-5 December I946

$\begin{array}{rrr}0 & - & 17 \\ 5 & 9 & -1 \\ 25 & 7 & 20 \\ 50 & 22 & 26 \\ 70 & 12 & 64 \\ 0 & 27 & 19 \\ 5 & 16 & 7 \\ 25 & 9 & 10 \\ 50 & 9 & 24 \\ 70 & 14 & 53 \\ 100 & 27 & 28\end{array}$

Cruise A, 6-8 January 1947

$\begin{array}{rcc}5 & - & 37,25,18 \\ 25 & - & 28,32,14 \\ 50 & - & 39 \\ 70 & - & 130,73,10 \\ 5 & - & 6 \\ 25 & - & 93 \\ 50 & - & 6,76 \\ 80 & - & 69 \\ 5 & - & 10 \\ 25 & - & 7 \\ 80 & - & 53 \\ 5 & - & 34 \\ 25 & - & 36 \\ 50 & - & 26 \\ 95 & - & - \\ 25 & - & 0 \\ 50 & - & 6 \\ 75 & - & 28 \\ 100 & - & 8 \\ 0 & - & 23 \\ 5 & - & 30,21,36 \\ 25 & - & 31,39,32 \\ 50 & 33 \\ 75 & 189,26 \\ 100 & - & 36 \\ 50 & - & 189\end{array}$

* Though the results are given in terms of $\mathrm{mg}$.-atom/100 $\mathrm{m} .{ }^{3}$, they are proportional to, and may be regarded equally as representing, weights of iron in single $150 \mathrm{ml}$. samples. For statistical purposes they are treated as such. For much of the development to follow, the distinction though subtle is fundamental. Mg.-atom $/ \mathrm{IOO} \mathrm{m} .^{3}$ are equivalent to $0.8376 \mu \mathrm{g}$. per $150 \mathrm{ml}$. The very slight difference between the litre and the cubic decimetre is ignored. 


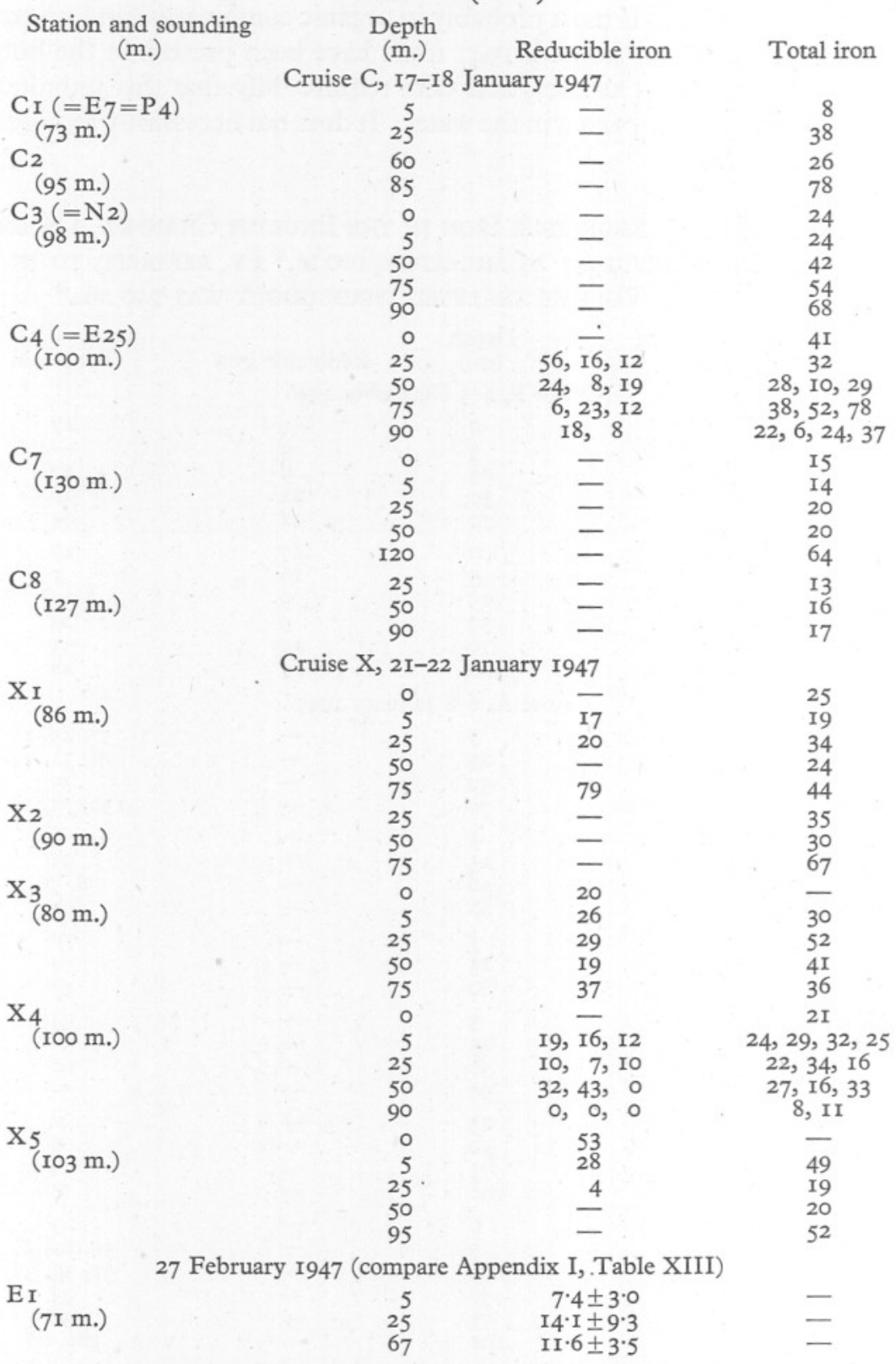

In the bottom water the mean content of reducible iron is rather less than in the upper layers but the difference is not statistically significant. Within the error of observation, with limited numbers of analyses, the reducible iron is 
randomly distributed throughout the whole water column. There is no significant variation with depth.

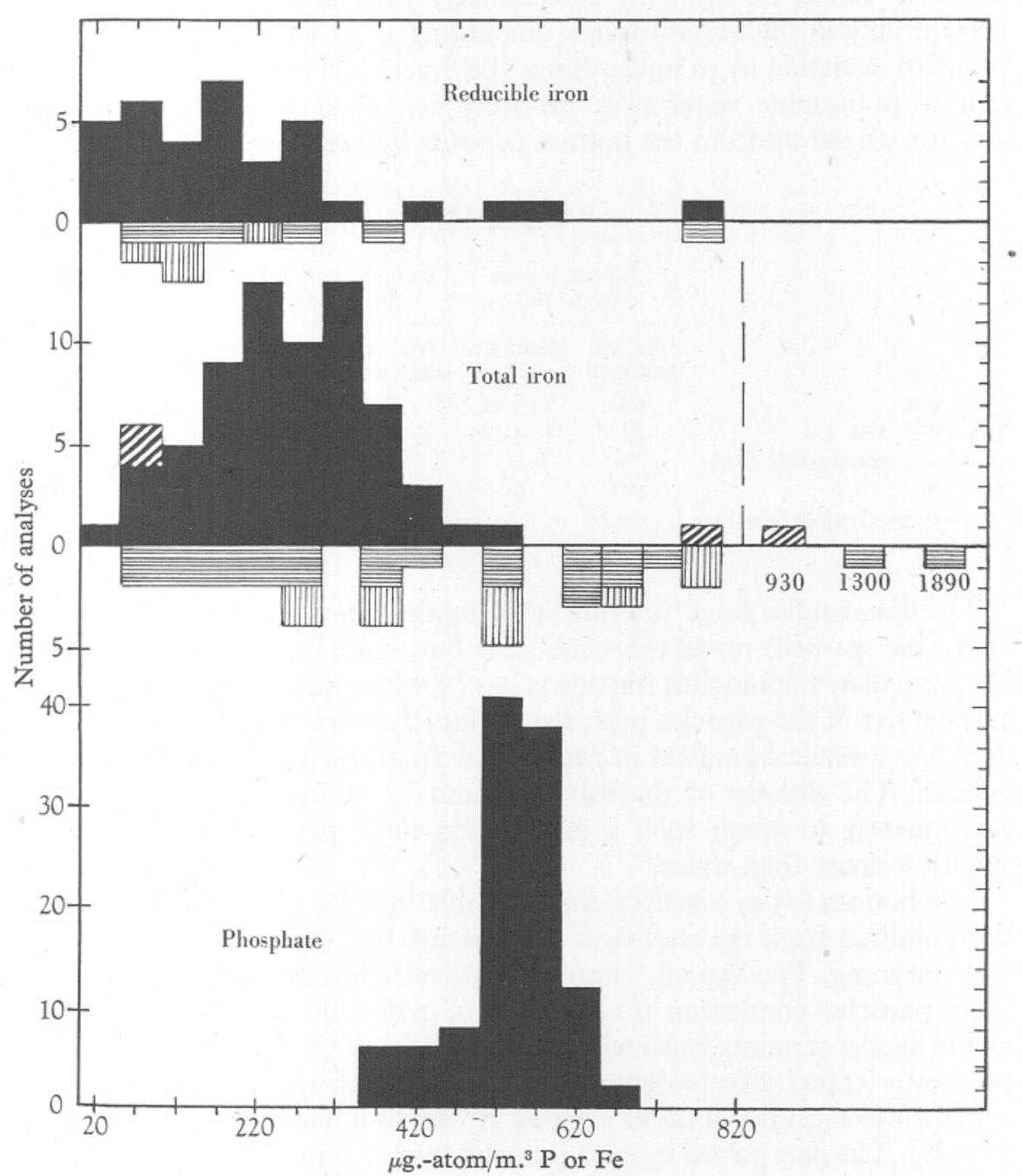

Fig. 2. Midwinter 1946-47. Numbers of iron and phosphate analyses grouped in classes with an argument of $50 \mu \mathrm{g}$.-atom $/ \mathrm{m} .^{3}$. (The first class comprises analyses of $0,10,20,30$ and $40 \mu \mathrm{g}$.-atom $/ \mathrm{m}^{.}{ }^{3}$, and is graphed as the median, $20 \mu \mathrm{g}$.-atom $/ \mathrm{m}^{3}{ }^{3}$; and so on.) The iron analyses are separated as follows: black, samples from the upper water layers (between 0 and $50 \mathrm{~m}$.); horizontal hatching, samples from bottom water; vertical hatching, samples from intermediate layer $(23-37 \mathrm{~m}$. above bottom). The upper water samples from station $\mathrm{A}_{3}$ are cross-hatched.

By contrast the mean content of total iron in the bottom water is twice as great as in the upper layers. The disparity in the standard deviation is even 
greater $(3.5 / \mathrm{I})$. This increase in the total iron content of bottom water has been shown to be due neither to the reducible nor to the dispersed unreducible fraction. It can be due only to a coarsely particulate unreducible fraction present only in the bottom water, amounting to 32 units with the very large standard deviation of 36 units. Since this fraction is only set free after oxidation with bromine water it is probably contained in particles of organic detritus stirred up from the bottom deposits by turbulent water movements.

\section{TABLE III}

\begin{tabular}{|c|c|c|c|c|c|c|}
\hline & \multicolumn{2}{|c|}{$\begin{array}{l}\text { Upper layers } \\
\text { (0-50 m.) }\end{array}$} & \multicolumn{2}{|c|}{$\begin{array}{l}\text { Intermediate layer } \\
\quad(60-75 \mathrm{~m} .)\end{array}$} & \multicolumn{2}{|c|}{ Bottom layer } \\
\hline & $\begin{array}{l}\text { No. of } \\
\text { analyses }\end{array}$ & $\begin{array}{l}\text { Mean and } \\
\text { S.D. }\end{array}$ & $\begin{array}{l}\text { No. of } \\
\text { analyses }\end{array}$ & $\begin{array}{l}\text { Mean and } \\
\text { S.D. }\end{array}$ & $\begin{array}{l}\text { No. of } \\
\text { analyses }\end{array}$ & $\begin{array}{l}\text { Mean and } \\
\text { S.D. }\end{array}$ \\
\hline $\begin{array}{l}\text { Total iron } \\
\text { Reducible iron }\end{array}$ & 68 & $\begin{array}{l}25 \pm I I \\
I 9 \pm I 4\end{array}$ & 8 & $46 \pm 17$ & 23 & $5 \mathrm{I} \pm 38$ \\
\hline $\begin{array}{l}\text { Dispersed unreducible iron } \\
\text { (max.) }\end{array}$ & - & 6 & - & 6 & - & 6 \\
\hline $\begin{array}{l}\text { Coarsely particulate iron } \\
\text { (min.) }\end{array}$ & - & $\circ$ & - & $26( \pm 15)$ & - & $32( \pm 36)$ \\
\hline
\end{tabular}

The few samples from 'intermediate' depths (60-75 m. depth and $23-37 \mathrm{~m}$. above the sea-bed) reveal the same story but, since the standard deviation of the particulate unreducible fraction is less ( \pm 15 compared with \pm 36 units), the average size of the particles must also be less than nearer the bottom. There is therefore a vertical gradient in particle size from the upper layers towards the bottom. The density of the water column in January 1947 was uniform; consequently to attain such a distribution these particles must have been slightly heavier than water.

The bottom $(75 \mathrm{~m}$.) analysis for reducible iron (79 units) at station XI has been omitted from the statistical examination but, none the less, it seems to have meaning. The $150 \mathrm{ml}$. sample must have contained one or possibly two large particles containing $0 . \mathrm{I} \mu \mathrm{g}$.-atom of reducible iron. Such a particle would almost certainly be suitable chemically for direct assimilation by plants; physically it must be far too large to be handled by any single cell for it would be sufficient to meet the needs of a strong growth of phytoplankton in many litres of water. The part played by such particles cannot at present be fairly assessed.

To sum up, the bottom water contained:

(a) A well dispersed unreducible organic iron fraction amounting to about 6 units.

(b) A particulate reducible fraction amounting to about $\mathrm{I} 3 \mathrm{3}$ units. This was probably flocculent ferric hydroxide or phosphate.

(c) A coarsely particulate or detrital unreducible fraction amounting to about 30 units.

(d) Occasional relatively large particles containing much reducible iron. 
Ferric hydroxide or phosphate, precipitated, flocculated or excreted at middepths, will be caught by filter-feeding zooplankton, adsorbed upon phytoplankton or will settle slowly to the bottom. There, turbulence due to tides, currents and other water movements tend to keep these particles in intermittent movement. Sessile and free-swimming animals feeding on and near the bottom will also add their quota of iron-containing faeces. During passage through the intestines of filter feeders, some of the iron may be dissolved by acid digestive juices and excreted in solution whilst some will become incorporated in an organic matrix of mucilage and waste products which, after excretion, will tend to be broken down by bacteria so dispersing the iron in finer particles. The distribution of iron amongst these several fractions in the bottom water therefore must provide the key to the return of iron into circulation in shelf waters.

The earlier diatom outbursts in coastal areas believed by Gran (I93I, I933) to be due to iron derived from the land could equally well be ascribed to iron derived by vertical mixing from such an iron-rich layer of bottom water on a shelf. A heavy storm should increase the iron content of the photosynthetic layers at the expense of the bottom water and deposits. This may be the meaning of the very high and erratic results at station $\mathrm{A}_{3}$ (cf. Fig. 2).

\section{Possible Removal of Particulate Iron from Bottom Water by Molluscs}

Station $\mathrm{X}_{4}\left(49^{\circ} 30^{\prime} \mathrm{N}\right.$., $5^{\circ} 00^{\prime} \mathrm{W}$.) is unique, for there in the bottom water triplicate analyses failed to detect any reducible iron, total iron was very low (the duplicate analyses of 8 and II units being 15 units less than in the overlying water) whilst the phosphate distribution indicates active removal of particulate ferric phosphate from the water (p. 299). Nothing remotely like this was found at any other station; that this water was of 'south-western' origin is no explanation. The absence of particulate matter near the bottom called to mind the conditions in the mussel-purification tanks at Conway, North Wales, when the molluscs placed in turbid estuarine water have been actively at work for a few hours. No physical cause for the state of affairs at station $\mathrm{X}_{4}$ is to be seen so that the conclusion that the water had been clarified by a large population of bottom suspension feeders seems the only reasonable alternative.

Mr H. P. Sherwood (private communication) at Conway placed a single mussel at the bottom of a litre-measuring cylinder about $0.4 \mathrm{~m}$. high and covered it with a thick suspension of red oxide $\left(\mathrm{Fe}_{2} \mathrm{O}_{3}\right)$ in estuarine water. In I hr. the mussel had cleared much of the suspension from the water whilst in $2 \mathrm{hr}$. no trace of the opacity could be seen. Given a certain amount of tidal mixing a bed of mussels should have no difficulty in the course of a few days in clarifying a bottom layer of water 5-10 $\mathrm{m}$. thick.

Mussels do not live at a depth of $90 \mathrm{~m}$. but, according to $\mathrm{Mr} \mathrm{G}$. A. Steven, an organism with similar feeding habits, the large mollusc, Pinna, does. 
Capt. Creese of the Laboratory's research vessel Sabella, when asked where he would look for Pinna, gave a ground including the position of station $\mathrm{X}_{4}$ and no other position investigated during the winter cruises. Furthermore, on 20 July I 936 at station I, well within this ground, zero reducible and total iron was found at the bottom (Table V). If a bed of molluscs, such as Pinna, does have such a marked effect on the iron content of the bottom water, further lines of investigation would open up. Acting over a period of time the molluscs would strip the iron from the water column, converting it first into faeces and much pseudo-faeces which would tend to accumulate in bottom deposits and return only slowly to the water. Failing replenishment by water from areas outside the beds, the surface flora would in time be adversely affected both qualitatively and quantitatively by shortage of iron. Thus, in certain hydrological circumstances, an inverse relationship may develop between a dense bottom molluscan fauna and the phytoplankton production many metres above. Such an area may prove to be adverse to early spring outbursts of phytoplankton (cf. p. 287).

\section{Distribution and Size of Large Particles of Ferric Hydroxide}

The whole of the variability of total iron in the uppermost $50 \mathrm{~m}$. appears to be due to the reducible fraction composed, presumably, of flocks of ferric hydroxide and phosphate. In January 1947 it amounted to I9.3 units (mg.-atom $/ \mathrm{m}^{3} \times$ I00) (p. 310). The dispersed unreducible fraction (6 units) contributed little to the variance ${ }^{1}$ of total iron for which most analyses are available. However, the variance for neither total nor reducible iron as calculated in Appendices II and III is appropriate for calculating the average size and numbers of the particles, since variation between stations would be included. Eight samples drawn from between $\mathrm{O}$ and $50 \mathrm{~m}$. had been analysed in triplicate or quadruplicate for total iron, viz. A I, 5 m.; A I, 25 m.; A 7, 5 m.; A 7, 25 m.; $\mathrm{C}_{4}, 50 \mathrm{~m}$.; $\mathrm{X}_{4}, 5 \mathrm{~m}$.; $\mathrm{X}_{4}, 25 \mathrm{~m}$. and $\mathrm{X}_{4}, 50 \mathrm{~m}$. For these there are twenty-five analyses on sub-samples, eight means and seventeen degrees of freedom, the variance between subsamples being 64.8 square units (p. 310).

A fair estimate of the variance introduced by the chemical technique is to be had from Appendix I, Table XIII. The standard deviation of 3.08 units for station E I, $25 \mathrm{~m}$. Series I corresponds to a variance of 9.5 square units. Therefore 64.8 less $9.5(=55.3)$ is the final estimate of the variance between different readings of total iron from one position in the water column when the size of each water sample is $150 \mathrm{ml}$. That is, 55.3 represents the sampling variance for iron in a volume of $150 \mathrm{ml}$. of sea water in the western English Channel in January 1947. Furthermore, the amount of iron subjected to this

1 The limitation that the variance applies only to the sample volume of $150 \mathrm{ml}$. needs constantly to be borne in mind, e.g. it is not a function of the cubic metre. 
sampling variance is $19 \cdot 3$ units. A variance of such magnitude $\left(55^{\circ} 3\right)$, it would seem, can arise only because the iron is aggregated in particles. Two questions may be posed: (I) how many particles are there? and (2) what is their size expressed in terms of their iron content?

According to $\mathrm{Mr}$ G. M. Spooner (private communication) random variation in numbers of particles dispersed in a volume of fluid (of which they form an insignificant fraction) may be expected to conform to the Poisson distribution.

The Poisson frequency distribution is a special limiting case of the binomial distribution, derived from the binomial expansion $(p+q)^{n}$, when $p$ is a very small fraction but $n$ correspondingly large so that $n p$ remains an ordinary number. In our example the volume of water is regarded as an aggregate of a large number $(n)$ of particle-sized units, of which a small proportion $(p)$ belong to the special iron-containing particles under investigation, the rest, a proportion $q$, to the medium. The mean number of iron-containing particles in the given volume is $n p$. The variance amongst different samples is also $n p$, since the general binomial variance of $n p q$ becomes $n p$ when $q$ is not significantly different from unity. It is a characteristic property of the Poisson distribution that the Mean and Variance are equal. Identical values should therefore be obtained for the mean and variance when these are expressed as numbers of particles instead of as weights of iron per unit volume.

In the present instance the mean is 19.3 units of iron and the variance 55.3 sq.units. If it is supposed that the iron is distributed in a number of equal aggregates or particles, it at once follows that $55 \cdot 3 / 19 \cdot 3(=2.865$ units) represents the amount of iron per particle. (Converting by the factor given in the footnote to Table II this equals $0.240 \mu \mathrm{g}$. per particle.) There will thus be a mean number of $19 \cdot 3 / 2.865(=6.74)$ particles per I50 ml. This is equivalent to 45 particles per litre. This estimated mean number will scarcely be affected even if there is an appreciable range of variation in either particle-size or in iron-content of particles. An assessment of the accuracy of this result, not rigorously statistical, suggests that the number of particles could just possibly have been as low as 30 or as high as 80 particles per litre and almost certainly was not outside these limits.

To arrive at a rough estimate of the size of such a particle let us assume it to have a specific gravity of I.I and an iron content of Io $\%$. Such a particle would occupy

$$
\frac{0.24 \times I O^{-6} \times I O}{I \cdot I}=2.18 \times 10^{-6} \text { c.c. }
$$

If the particle is spherical and of radius $r$, then $r=0.08 \mathrm{~mm}$.

That is, there were about 45 large particles per litre of water with a diameter averaging about $\mathrm{I} 60 \mu$. If the iron content had been assumed to be $\mathrm{I} \frac{1}{4} \%$ instead of $10 \%$, this diameter would have worked out at $320 \mu$.

The result means that in the sea water of the English Channel between the surface and $50 \mathrm{~m}$. at midwinter in $1946-47$ four-fifths of the iron was 
associated with a very few large particles. We have to ask ourselves whether such a surprising result is possible and what such particles might be:

No collections for phytoplankton were made but, during the first two cruises, Mr P. S. B. Digby was on board and made some quantitative collections between $50 \mathrm{~m}$. and the surface for his studies upon copepods. He used a Harvey quantitative net with I20 meshes per linear inch. Such a net would catch most, though not all, of the particles of the size we are considering. Two of these catches were generously placed at my disposal and Dr T. J. Hart has kindly examined them for me. In the catch from station $\mathrm{C}_{4}$ he found 45 'large particles' per litre which had diameters of the order of $100 \mu$. This number is minimal and half made up by partially disintegrated colonies of Phaeocystis. In the catch from station $\mathrm{A}_{7}$ he was able to find only nine such particles per litre; nearly half were faecal pellets whilst a quarter were cells of the alga Halosphaera viridis (average $\mathrm{I} 20 \mu$ ).

That diatoms may heavily adsorb ferric hydroxide and phosphate is known (Harvey, I937a) but whether these particles did in fact contain sufficient iron to account for our analytical findings is not known. The material was collected for very different ends and no exact agreement could be expected. All that can be said is that particles in sufficient numbers and of the right size were present to make the analytical results not unreasonable.

As the spring advanced the numbers of large diatoms, of large herbivores and of their faecal pellets must have increased rapidly. The number of smaller organisms also would have increased. The iron associated with living matter must have passed through many cycles in the course of the spring, though only a small part may have been truly metabolized by plants or animals. The iron would have become distributed amongst a larger and larger number of organisms and faecal pellets whilst the percentage content of each one, on an average, would have become less and less. So far as iron is concerned, this is equivalent to more and smaller particles. With about 370 particles or organisms per litre the variance would become about I sq.unit and any possibility of establishing the presence of particulate iron by statistical study of replicate chemical analyses would vanish. There is therefore less chance of establishing the thesis in these waters at seasons other than midwinter.

Between 9 March and I4 November 1934, analyses of iron were carried out upon catches made at station $\mathrm{L}_{4}$ with the Harvey quantitative net (200 meshes per linear inch). The maximum iron content was found on 20 March coincident with the phytoplankton maximum, $4 \mathrm{I} \mu \mathrm{g}$.-atom per cu.m. of water filtered ( $\equiv 4$. I units) (Harvey et al. I935; Cooper 1935). During the next fortnight the plankton-iron fell to one-third whereas the plankton-phosphate remained almost constant. As the spring advanced the ratio of iron to phosphate expressed in gram-atoms fell from 2.55 to 0.45 , whilst during the autumn it rose from 0.48 to I.93 on I4 November. It is likely therefore that at midwinter the ratio would have been still higher. None the less, the gap 
between the observed maximum of $4 \cdot I$ units caught with the Harvey net on 20 March 1934 and 19.3 units indicated by the present study at midwinter 1946-47 is a large one to bridge.

The analytical method has been tested under conditions where the iron has intentionally been kept as highly dispersed as possible. There is evidence, not consistent enough to publish, that if an iron solution, ferric or ferrous, is added to sea water at its natural $\mathrm{pH}$ around $8 . \mathrm{I}$, some of the added iron becomes undeterminable. Results agree poorly. Possibly some iron flocculates, though not visibly to the naked eye, and the method does not quickly attack these flocks (cf. Buch, I942). If flocks or ferruginous particles are present analytical errors may be exaggerated, whereas with well-dispersed iron they will not arise. In such case, the general picture outlined here is correct but the variances may have been somewhat exaggerated so that the iron in the sea may have been distributed amongst more and somewhat smaller particles than the present study has suggested.

\section{The Horizontal Distribution of Iron}

The horizontal distribution of phosphate or other truly dissolved nutrient is best studied in terms of the integral mean content of the vertical water column which takes account of the unequal spacing of standard depths (Cooper, I933, p. 722, as 'average nutrient salt content of the water column'). For a randomly distributed constituent such as total iron, this integral mean would have value only if arithmetic means of a large number of analyses were first available at each depth and station. The most convenient measure of the total stock of iron in the English Channel in winter is therefore the simplest, the arithmetic mean of all analyses at a station irrespective of depth. No clear picture emerges from charting single stations, but one can be obtained by arranging the data for stations at which iron and phosphate analyses are both available in three groups of increasing phosphate content (Table IV, fourth column).

Table IV. Ratio of Total Iron to Phosphate

(Mg.-atom $/ \mathrm{m}^{3} \mathrm{Fe}$ and $\mathrm{P} \times$ IOO)

Phosphate

integral mean for whole water column

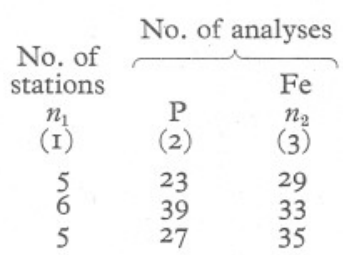

\begin{tabular}{|c|c|}
\hline $\begin{array}{c}\text { Range } \\
(4)\end{array}$ & $\begin{array}{l}\text { Average } \\
\text { for } n_{1} \\
\text { stations } \\
\text { (5) }\end{array}$ \\
\hline $\begin{array}{l}37-50 \\
51-55 \\
56-63\end{array}$ & $\begin{array}{l}43 \cdot 4 \\
53 \cdot 2 \\
59 \cdot 4\end{array}$ \\
\hline
\end{tabular}

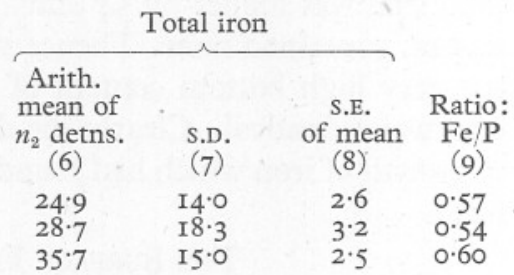

The standard error of the means (col. 8) shows that the increase in total iron with phosphate given in the sixth column is just statistically significant. The inclusion of bottom analyses somewhat increases the standard deviations 
(col. 7) compared with those for 0-50 m. in Table XIV. The ratios of total iron to phosphate (arithmetic mean average of integral means) (col. 9) are not far from constant. The analyses of the midwinter maximum of phosphate therefore gave a measure of the statistical probability of occurrence of total iron $(0.57 \times$ concentration of phosphate). At any one station the total iron calculated from this ratio is as likely to represent the total iron content as the limited number of analyses actually performed.

For computing Table IV, stations $\mathrm{C}_{1}$ and $\mathrm{C}_{2}$ were treated as one and, in addition to station $\mathrm{A}_{3}$ (p. 282), the analyses at $\mathrm{A}$, $70 \mathrm{~m}$. (I30 units) and $\mathrm{A}_{7}$, I00 m. (I89 units) were omitted. These analyses were grossly at variance with replicates and their inclusion, whilst increasing the spread of the mean of total iron in the fifth column, nearly doubles the standard errors of the mean in the two higher groups. Both analyses were on bottom water making it likely that single particles of bottom detritus of very high iron content were caught by the bottle; both are better left out.

\section{The Distribution of Iron IN I933-34}

When the I933-34 work was reported (Cooper, I935), the reason for the erratic results obtained was not clearly understood and to economize space figures for the average content of the water column only were presented. Though the data are not sufficiently homogeneous for a satisfactory statistical study, further information of value for the present account may be had from them.

(I) On I5 December I933, at all the stations between L I and L 5 (Eddystone) and at E I, the total iron content of surface water sampled with a wooden bucket was high (32-43 units), whilst that at 5, 50 and $69 \mathrm{~m}$. was a mere $7-9$ units suggesting that about 30 units was in some way associated with the surface layer.

(2) On I2 February I934 at stations L4, L6, E I and at a position midway between $\mathrm{E}_{1}$ and $\mathrm{E}_{2}$ erratic results were obtained, the surface results for total and reducible iron being especially erratic and high.

(3) On 20 March I934 at the peak of the spring outburst at $\mathrm{L}_{4}$ surface total iron was higher by 54 units than in deeper water whilst at E I the water at $5 \mathrm{~m}$. contained none. Thence to the bottom there was a graded increase to the very high bottom content of 54 units. At all depths reducible and total iron were identical. Clearly the diatoms had stripped the water in their zone of growth of iron which had found its way to the bottom in a readily attackable form.

\section{The Surface Film of Ferric Hydroxide}

In 1933-34 concentration of iron in the surface layers was frequent. Yet at midwinter I946-47 statistical examination showed no such surface concentration. The answer to this contradiction arises from the different methods of 
surface sampling used in the two years. In 1946-47 all surface samples were taken with the Nansen-Pettersson water-bottle submerged just beneath the surface and not breaking water. It sampled the uppermost metre of water but not the surface film. The wooden bucket used throughout I933-34 definitely included an area of the surface film to which it is therefore reasonable to attribute the high surface results in that year.

Harvey $(1937 b)$ has shown that an unprotected sol of ferric hydroxide in sea water is electropositive whilst a similar sol protected by gum arabic is electronegative. A sol afforded definite protection by albumen carried either no charge or one too small to be measured with the apparatus employed. Mokrushin (1947) has found that on ageing colloidal solutions of positively charged ferric hydroxide a very thin invisible surface film is formed spontaneously by coagulation, whereas no such film is formed on sols of negatively charged ferric hydroxide. From these and many other observations he has concluded that this surface coagulation of electropositive sols results in the formation of a uni-micellar film, at first only a network-later becoming a compact solid film. The thickness of this layer of ferric hydroxide was 3-4 $\mathrm{m} \mu$ and it was further deduced that micelles in the hydrosol were lamellar or plate-like with a diameter of $30-40 \mathrm{~m} \mu$. One such micelle would weigh about $10^{-17} \mathrm{~g}$. and cannot be identified with the particles already discussed. A solid film of ferric hydroxide, I sq. $\mathrm{cm}$. in area, $3.5 \mathrm{~m} \mu$ thick and having a specific gravity of 3.5 would weigh $\mathrm{r} \cdot 0 \mu \mathrm{g}$.

The wooden bucket used for surface sampling was about $30 \mathrm{~cm}$. in diameter and was usually filled to a depth of about $20 \mathrm{~cm}$. or a volume of I4 1 . If we suppose that $(a)$ the sea surface was uniformly covered with such a unimicellar layer, (b) that a disk of the surface $30 \mathrm{~cm}$. in diameter (containing $\pi \times \mathrm{I} 5^{2} \times \mathrm{I} \cdot 0 \mu \mathrm{g} .=700 \mu \mathrm{g}$. ferric hydroxide) was sampled by the bucket and (c) that pouring from bucket to storage bottle led to fair sampling of the superficial and bulk phases, then $700 \mu \mathrm{g}$. ferric hydroxide would have become distributed in I4 1. of water. That is, each litre would appear to contain $50 \mu \mathrm{g}$. ferric hydroxide or $0.47 \mu \mathrm{g}$.-atom of Fe. This figure gives a rough maximum for the amount of iron present in a sample taken from the surface by dipping up with a bucket and attributable to a surface unimicellar film of electropositive unprotected ferric hydroxide. The results of I5 December 1933 would agree with two-thirds of the surface of the sea being covered by such a film. Naturally only the order of magnitude of this calculation has significance, but its essential soundness is supported by Dr W. R. G. Atkins's observation (private communication) that the iridescent 'oily' film frequently observed on bog ponds consists largely of ferric hydroxide. This is apparently well known to limnologists. 
Table V. Hydrological data, Cruise of 20-22 July i936

\begin{tabular}{|c|c|c|c|c|c|c|c|c|c|c|}
\hline \multirow[b]{3}{*}{$\begin{array}{c}\text { Station } \\
\text { no. }\end{array}$} & \multirow[b]{3}{*}{ Position } & \multirow[b]{3}{*}{$\begin{array}{l}\text { Date and } \\
\text { time } \\
\text { (G.M.T.) } \\
\text { July }\end{array}$} & \multirow[b]{3}{*}{$\underset{(\mathrm{m} .)}{\text { Depth }}$} & \multirow[b]{3}{*}{$\begin{array}{l}\text { Temp. } \\
\left({ }^{\circ} \mathrm{C} .\right)\end{array}$} & \multirow[b]{3}{*}{$\begin{array}{c}\text { Sal. } \\
(\% / \%)\end{array}$} & \multirow[b]{3}{*}{$\begin{array}{c}\mathrm{PO}_{4}-\mathrm{P} \\
(\mathrm{mg} \cdot-\text { atom } / \\
\left.\text { m. }{ }^{3} \times \mathrm{IOO}\right)\end{array}$} & \multicolumn{4}{|c|}{ Iron (mg.-atom/m. × loo) } \\
\hline & & & & & & & \multirow[b]{2}{*}{ Total } & \multicolumn{3}{|c|}{ Reducible } \\
\hline & & & & & & & & $\begin{array}{l}\text { Unfiltered } \\
\text { water }\end{array}$ & $\begin{array}{l}\text { Membrane } \\
\text { filtered } \\
\text { at pH } 8\end{array}$ & $\begin{array}{l}\text { Membrane } \\
\text { filtered } \\
\text { at } \mathrm{pH} 4\end{array}$ \\
\hline I & $\begin{array}{r}50^{\circ} 08^{\prime} \\
4^{\circ} 39^{\prime \prime} \quad 30^{\prime \prime} \text { W.' }\end{array}$ & $\begin{array}{l}20 \\
\text { I } 415\end{array}$ & $\begin{array}{l}\text { I0 } \\
65\end{array}$ & $\begin{array}{l}13.4 \\
10.9\end{array}$ & $\begin{array}{l}34.50 \\
34.59\end{array}$ & $\begin{array}{r}4 \\
19\end{array}$ & $\begin{array}{l}4 \\
\circ\end{array}$ & $\begin{array}{l}4 \\
0\end{array}$ & 二 & 二 \\
\hline 2 & $\begin{aligned} 49^{\circ} & 56^{\prime} \\
5^{\circ} & \mathrm{N} . \\
3^{\prime} & \mathrm{W} .\end{aligned}$ & $\begin{array}{l}20 \\
175^{\circ}\end{array}$ & $\begin{array}{l}10 \\
60\end{array}$ & $\begin{array}{l}\text { II } 65 \\
\text { II } 65\end{array}$ & $\begin{array}{l}34 \cdot 67 \\
34 \cdot 70\end{array}$ & $\begin{array}{l}16 \\
39\end{array}$ & $\begin{array}{r}13 \\
2\end{array}$ & $\begin{array}{l}9 \\
2\end{array}$ & 二 & 二 \\
\hline 3 & $\begin{array}{r}49^{\circ} 47^{\prime} \text { N., } \\
5^{\circ} 22^{\prime} \text { I0" W. }\end{array}$ & $\begin{array}{c}20 \\
2000\end{array}$ & $\begin{array}{l}\text { I0 } \\
85\end{array}$ & $\begin{array}{l}13 \cdot 4 \\
\text { II. } 52\end{array}$ & $\begin{array}{l}34 \cdot 80 \\
35 \cdot 18\end{array}$ & $\begin{array}{r}9 \\
3 \mathrm{I}\end{array}$ & $\begin{array}{r}4 \\
23\end{array}$ & $\begin{array}{r}4 \\
23\end{array}$ & 二 & 二 \\
\hline 4 & $\begin{array}{r}49^{\circ} 29^{\prime}, 40^{\prime \prime} \text { N., } \\
5^{\circ} 38^{\prime} 20^{\prime \prime} \text { W. }\end{array}$ & $\begin{array}{l}20, \\
2330\end{array}$ & $\begin{array}{l}\text { Io } \\
80\end{array}$ & $\begin{array}{l}15 \cdot 57 \\
\text { II. } 28\end{array}$ & $\begin{array}{l}34 \cdot 99 \\
35 \cdot 28\end{array}$ & $\begin{array}{r}6 \\
31\end{array}$ & $\begin{array}{r}21 \\
0\end{array}$ & ० & 二 & 二 \\
\hline 5 & 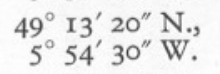 & $\begin{array}{l}\text { 21, } \\
\text { O3IO }\end{array}$ & $\begin{array}{l}\text { Io } \\
90\end{array}$ & $\begin{array}{l}15.57 \\
\text { II. }\end{array}$ & $\begin{array}{l}34 \cdot 97 \\
34 \cdot 39\end{array}$ & $\begin{array}{r}5 \\
56\end{array}$ & $\begin{array}{l}38 \\
36\end{array}$ & $\begin{array}{r}9 \\
\text { II }\end{array}$ & 二 & - \\
\hline 6 & $\begin{array}{l}49^{\circ} 08^{\prime}, 20^{\prime \prime} \text { N., } \\
6^{\circ} 24^{\prime} \text { W. }\end{array}$ & $\begin{array}{l}21, \\
0655\end{array}$ & $\begin{array}{r}\text { I0 } \\
\text { I00 }\end{array}$ & $\begin{array}{l}15.0 \\
10.71\end{array}$ & $\begin{array}{l}34 \cdot 98 \\
35 \cdot 44\end{array}$ & $\begin{array}{r}4 \\
45\end{array}$ & $\begin{array}{l}23 \\
43\end{array}$ & $\begin{array}{r}9 \\
\text { II }\end{array}$ & 二 & 二 \\
\hline 7 & $\begin{array}{c}49^{\circ} 25^{\prime} 40^{\prime \prime} \mathrm{N} . \\
6^{\circ} 9^{\prime} 30^{\prime \prime} \mathrm{W}\end{array}$ & $\begin{array}{l}21 \\
1040\end{array}$ & $\begin{array}{r}10 \\
\text { I00 }\end{array}$ & $\begin{array}{l}15.25 \\
10.87\end{array}$ & $\begin{array}{l}34 \cdot 92 \\
35 \cdot 34\end{array}$ & $3^{5}$ & $\begin{array}{l}16 \\
\text { I8 }\end{array}$ & $\begin{array}{r}16 \\
9\end{array}$ & 二 & 二 \\
\hline 8 & $\begin{array}{l}49^{\circ} 43^{\prime} \text { N., } \\
5^{\circ} 55^{\prime} \text { W. }\end{array}$ & $\begin{array}{l}21 \\
1410\end{array}$ & $\begin{array}{l}\text { Io } \\
80\end{array}$ & $\begin{array}{l}\mathrm{I} 4 \cdot 3 \\
\mathrm{II} \cdot \mathrm{I}\end{array}$ & $\begin{array}{l}34 \cdot 99 \\
35 \cdot 32\end{array}$ & $\begin{array}{r}3 \\
32\end{array}$ & $\begin{array}{l}18 \\
21\end{array}$ & $\begin{array}{r}9 \\
30\end{array}$ & 二 & 二 \\
\hline II & $\begin{array}{c}50^{\circ} 2^{\prime} 30^{\prime \prime} \text { N., } \\
4^{\circ} 26^{\prime} 40^{\prime \prime} \text { W. }\end{array}$ & $\begin{array}{l}22, \\
1220\end{array}$ & $\begin{array}{r}0 \\
5 \\
10 \\
25 \\
50 \\
65\end{array}$ & $\begin{array}{l}\text { I5.0 } \\
\text { I } 4.1 \\
\text { I } 3.15 \\
\text { II. } 85 \\
- \\
\text { II.29 }\end{array}$ & $\begin{array}{l}34.45 \\
34.45 \\
34.47 \\
34.61 \\
34.58 \\
34.56\end{array}$ & $\begin{array}{r}6 \\
6 \\
7 \\
24 \\
24 \\
24\end{array}$ & $\begin{array}{r}16 \\
16 \\
18 \\
2 \\
9 \\
0\end{array}$ & $\begin{array}{l}2 \\
2 \\
4 \\
2 \\
0 \\
0\end{array}$ & $\begin{array}{l}0 \\
0 \\
0 \\
0 \\
0 \\
0\end{array}$ & $\begin{array}{r}16 \\
9 \\
4 \\
2 \\
0 \\
2\end{array}$ \\
\hline
\end{tabular}




\section{The Distribution of Iron IN July 1936}

In July 1936 a cruise was made by S.S. Salpa to the southward of the Scilly Isles with Mr F. S. Russell and Mr P. H. T. Hartley on board. Ten stations were worked with the young fish trawl and eight with the Nansen-Pettersson water-bottle at $\mathrm{I0} \mathrm{m}$. and near the bottom. The temperature, salinity (analyses by the Government Chemist), inorganic phosphate and reducible and total iron, determined on the water samples, are given in Table V. Station II, about 3 miles to the westward from the position of station E I, was worked for a full hydrographical depth series, but not for the young fish trawl.

Since there was a strongly marked thermocline throughout the area except at station 2, no physical or chemical resemblance need be expected between the water at $10 \mathrm{~m}$. and that at the bottom. The young fish trawl may sample both layers and, in any event, the two species of Sagitta, of such value in characterizing water masses in the area, migrate daily across the thermocline. One species though perhaps initially associated with only one layer may become apparently associated with both. It is necessary, therefore, to compare the Sagitta distribution with the hydrological data for both layers separately.

\section{(a) Comparison in Bottom Waters}

The bottom waters may be divided into three clearly contrasted groups (Table VI).

Table VI. Hydrological Observations at the Bottom on 20-22 JULY I936 COMPARED WITH CATChES OF SAGITTA

\begin{tabular}{|c|c|c|c|c|}
\hline & & Phosphate & $\begin{array}{c}\text { Iron } \\
\left(\text { mg.-atom } / \mathrm{m}^{3} \times \text { IOO) }\right.\end{array}$ & Sagitta \\
\hline Station & (m.) & $\left.\mathrm{m} \cdot{ }^{3} \mathrm{P} \times 100\right)$ & Reducible & elegans \\
\hline
\end{tabular}

Low salinity group:

$\begin{array}{rrr}34.56 & \text { II } & 65 \\ 34.59 & \text { I } & 65 \\ 34.70 & 2 & 6\end{array}$

34.70

$\begin{array}{ll}65 & 24 \\ 65 & 19 \\ 60 & 39\end{array}$

$\begin{array}{lll}0 & 0 \\ 0 & 0 & 0\end{array}$

Not determined
92
342

Medium salinity group:

$35 \cdot 18$

$35 \cdot 28$

$35 \cdot 32$

$35 \cdot 34$

$\begin{array}{rr}3 & 85 \\ 4 & 80 \\ 8 & 80 \\ 7 & 100\end{array}$

$$
\begin{aligned}
& 3 I \\
& 3 I \\
& 32 \\
& 38
\end{aligned}
$$

$$
\begin{array}{r}
23 \\
0 \\
30
\end{array}
$$

High salinity group:

$35 \cdot 39$
$35 \cdot 44$

$\begin{array}{lr}5 & 90 \\ 6 & 100\end{array}$

$\begin{array}{lcc}56 & \text { II } & 36 \\ 45 & \text { II } & 43 \\ \text { * } & \text { Night } & \text { stations. }\end{array}$

23
0
21
18

$\begin{array}{rl}5 & \text { I } \\ 284^{\star} & 0 \\ 0 & 0 \\ 54 & 0\end{array}$

Low salinity group. Three stations of very low salinity extending right to the bottom, relatively low phosphate, very low or zero reducible and total iron and a few Sagitta setosa. S. elegans was present in numbers exceeding S. setosa. 
Medium salinity group. Four stations with bottom salinity about $35.3 \%$, intermediate content of phosphate and of reducible and total iron and only a single $S$. setosa. S. elegans was present at three of the stations.

High salinity group. The two most westerly stations with salinities 35.39 and $35.44 \%$ had high phosphate and total iron, a large difference between reducible and total iron (28 units), no $S$. setosa and a great many S. elegans. These last stations were evidently occupied by truly 'elegans' water. Their high unreducible iron content supports the 1946-47 midwinter results in showing 'elegans' water to be relatively rich in this form of iron at the bottom.

\section{(b) Comparison of no m. Observations}

The Io $\mathrm{m}$. results are most conveniently arranged in ascending order of total iron content (Table VII). It will be seen than low total iron is associated

TABle VII. Hydrological Observations at IO M. DEPTH ON 20-22 JULY 1936 COMPARED With Catches OF SAGITTA Iron

(mg.-atom $\left./ \mathrm{m} .^{3} \times \mathrm{IOO}\right)$

$\overbrace{\text { Total Reducible Station }}$

Low total iron and salinity group:

$\begin{array}{rrrr}4 & 4 & 3 & 34 \cdot 80 \\ 4 & 4 & \text { I } & 34 \cdot 50 \\ \text { I3 } & 9 & 2 & 34 \cdot 67 \\ \text { I8 } & 4 & \text { II } & 34 \cdot 45\end{array}$
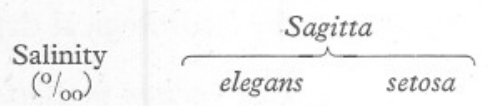

$\begin{array}{rr}5 & \text { I } \\ 92 & \text { I I } \\ 342 & \text { I2 } \\ \text { Not determined }\end{array}$

Not determined

\section{Phosphate (mg.-atom/ $\mathrm{m} .^{3} \times \mathrm{IOO}$ ?}

High total iron and salinity group:

$\begin{array}{lrrrrrr}\text { I6 } & \text { I6 } & 7 & 34.92 & 54 & 0 & 5 \\ \text { I8 } & 9 & 8 & 34.99 & 0 & 0 & 3 \\ \text { II } & 0 & 4 & 34.99 & 284^{\star} & 0 & 6 \\ 23 & 9 & 6 & 34.98 & 41 \text { IO } & 0 & 4 \\ 38 & 9 & 5 & 34.97 & 970^{\star} & 0 & 5\end{array}$

with the lower salinity water and presence of a few $S$. setosa. Relatively high total iron is associated with higher salinity water, complete absence of $S$. setosa and includes the stations with large catches of $S$. elegans. Reducible iron and phosphate tell little, but as far as a correlation can be seen low total iron marches with low reducible iron and relatively high and erratic phosphate, high total iron with relatively high reducible iron and uniformly low phosphate (3-6 mg.-atom $/ \mathrm{m}^{3}$ ).

The fresh water which had reduced the salinity of the stations nearer Plymouth had in no way enriched the store of iron; there the slender stock of iron was all reducible. The typical 'elegans' water at $6^{\circ} \mathrm{W}$. was much richer in both total iron and phosphate but the additional iron was mostly unreducible.

The complete vertical series at station II near $\mathrm{E}_{\mathrm{I}}$ is of interest. In one set of analyses the sea water was brought to $\mathrm{pH}_{4}$ (required acid determined by titration with bromophenol blue as indicator to an end-point matched against 
the same indicator in $M / 20$ potassium hydrogen phthalate) and left for $30 \mathrm{~min}$. before filtration through a collodion membrane of filtration time $20 \mathrm{sec}$. Whereas membrane filtration at $\mathrm{pH} 8 \cdot \mathrm{I}$ removed all the iron, at $\mathrm{pH} 4$ part had become dissolved and passed into the filtrate. Again nearly all the iron, in marked contrast to phosphate, had become concentrated above the thermocline. This partition of iron upwards is difficult to understand on physical grounds.

\section{COMPARABLe Results From North AMERICAN Waters}

Rakestraw, Mahncke \& Beach (1936) filtered a number of samples through Whatman No. 42 filter paper and then analysed the content of iron by coprecipitation of ferrous sulphide with magnesium hydroxide. Water from the Gulf of Maine, all collected in summer, contained very little iron; usually it was zero. Positive results (8-20 units) were, however, found on a number of surface samples, but whether these included the surface film or were more truly $0.5 \mathrm{~m}$. samples is not stated. Filtered samples from four deep stations in the Atlantic Ocean off New England were also analysed. Here also there was a tendency for surface results to be high and at other depths ranging from 50 to $3830 \mathrm{~m}$. iron was always detectable ( $2-25$ units). Thompson \& Bremner $(1935 b), 25-100$ miles off the continental shelf in the north-east Pacific, obtained very similar results for 'soluble' iron, i.e. iron which had passed a Whatman no. 42 filter paper. Seiwell (I935), by a method which included iron in detritus and organisms trapped in the water-bottle and is similar to the method for 'total' iron of the present paper, examined waters collected in December and August, also from the Gulf of Maine. The distribution there in December 1933 was similar to that in the English Channel in DecemberJanuary 1946-47. For two stations at which phosphate analyses were also made (Conseil International, I933) the total-iron/phosphate ratio may be worked out. At station $1880\left(42^{\circ} 45^{\prime}\right.$ N., $68^{\circ} 48^{\prime}$ W. $)$ on 6 December I933, the uppermost $50 \mathrm{~m}$. showed uniform distribution of salinity $(33.06 \%$, temperature $\left(7.14^{\circ} \mathrm{C}\right.$.) and phosphate ( 99 units) and high and variable iron content yielding a $\mathrm{Fe} / \mathrm{P}$ ratio ranging from 0.67 and $0.9 \mathrm{I}$. In the underlying water of markedly different structure, this ratio was only 0.44 . A position 70 miles to the eastward at station $1897\left(42^{\circ} 25^{\prime} \mathrm{N}\right.$., $67^{\circ} 06^{\prime} \mathrm{W}$. $)$ was characterized by a very much lower ratio $(0.13-0.25)$, not notably affected by a marked discontinuity at $100 \mathrm{~m}$. Comparable English Channel ratios are summarized in Table IV. It is evident that the relative abundance of iron and phosphate varies in different parts of the world much more than do nitrate and phosphate.

\section{Particulate Ferric Phosphate}

Occasionally in phosphate analyses, results are obtained which appear high compared with those from adjacent positions, vertically and horizontally. Contamination, or the widely recognized difficulties inherent in methods 
involving complex molybdates, provide explanations ready to hand. Routine calibration runs to determine salt error in phosphate analyses are now made in triplicate to enable 'untrustworthy' results to be rejected. It would now seem that these causes have been invoked too frequently, at any rate by the writer, to explain what is a truly variable property of the sea water itself.

Harvey (1937a) has pointed out that ferric phosphate as well as hydroxide is likely to be present in sea water in particulate form. If the distribution of ferric phosphate is as erratic as that of total iron, we should have an explanation of these 'untrustworthy' phosphate analyses. Cruise X provided several such, with vertical variations greater than would be anticipated in isothermal, isohaline water in unsettled weather. Let us assume that dissolved inorganic phosphate was indeed vertically uniformly distributed under the isothermal conditions obtaining and was represented by the smallest analysis found in each vertical series. Phosphate in other samples or sub-samples in excess of this smallest value would then represent particulate ferric phosphate randomly distributed. Although there is no clear correlation between this and the total iron content, one may be found with the total iron in excess of the smallest analysis for total iron found for each vertical series. Table VIII shows the first step in the calculation for station $\mathrm{X}_{4}$.

Table VIII. Approximate calculation of Particulate Ferric Phosphate at Station $\mathrm{X}_{4}$

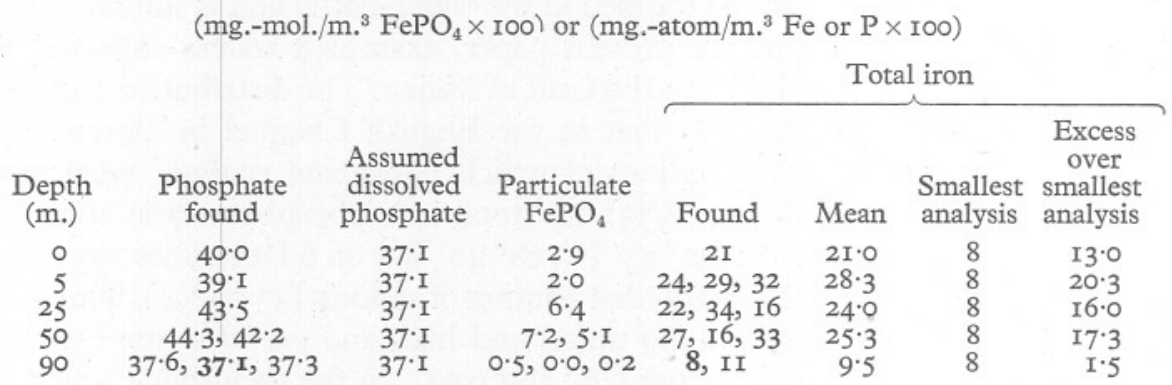

The 'particulate $\mathrm{FePO}_{4}$ ' (col. 4) found in this way from all separate phosphate analyses for the five Cruise $\mathrm{X}$ stations respectively were then arranged in groups of increasing $\mathrm{FePO}_{4}$ content and compared with the corresponding mean 'excess total iron' figures (as in the last column of Table VIII). The result of the calculation is set out in Table IX. Figures such as the duplicate phosphate results at station $\mathrm{X}_{4}, 50 \mathrm{~m}$. were entered twice as $7 \cdot 2$ and $5 . \mathrm{I}$, the same excess total iron figure, $17 \cdot 3$, being entered for both.

The results for station $\mathrm{X}_{5}, 5 \mathrm{~m}$. ('particulate $\mathrm{FePO}_{4}$ ', $\mathrm{O}$, and excess total iron, 30 units) are anomalous and affect the average for the first group in the way shown. The inference is strong that the irregularities in the determinations of inorganic phosphate are in fact due to random occurrence of particulate ferric 
phosphate and that this particulate ferric phosphate is associated with the largest particles or least well-dispersed fraction of the particulate iron. The ferric phosphate was most probably included in faecal pellets (Cooper, I948b).

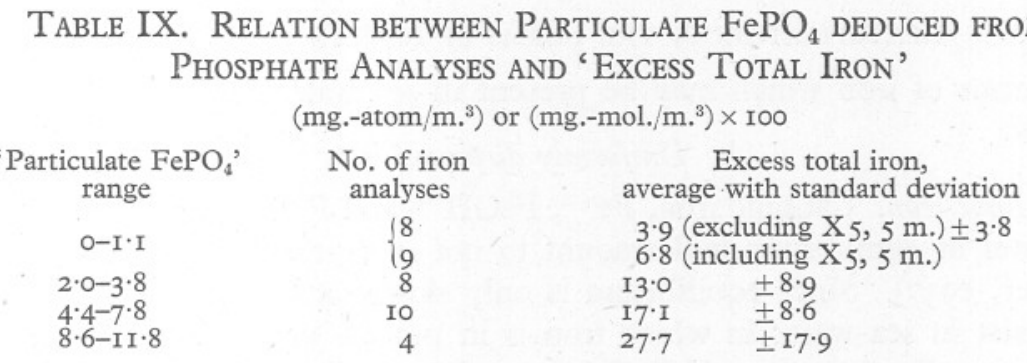

The assumption that the sample from each station giving the lowest analysis for phosphate contained no particulate $\mathrm{FePO}_{4}$ is, in general, unlikely to be true. The estimates of the distribution of ferric phosphate at the Cruise $\mathrm{X}$ stations set out in Table $\mathrm{X}$ are therefore minimal.

Table X. Minimal Particulate Ferric Phosphate content AT STATIONS ON CRUISE $\mathrm{X}$

\begin{tabular}{|c|c|c|c|c|c|c|}
\hline \multirow[b]{2}{*}{$\begin{array}{c}\text { Station ... } \\
\text { Depth (m.) }\end{array}$} & \multicolumn{5}{|c|}{ (mg.-mol. $/ \mathrm{m}^{3} \times$ roo) } & \multirow[b]{2}{*}{ Mean } \\
\hline & $\mathrm{XI}_{\mathrm{I}}$ & $\mathrm{X}_{2}$ & $\mathrm{x}_{3}$ & $\mathrm{x}_{4}$ & $\mathrm{x}_{5}$ & \\
\hline 0 & 0 & - & 0 & 2.9 & 4 & I.7 \\
\hline 5 & 4 & $9,0,5, \circ$ & I & $2 \cdot 0$ & 0 & $2 \cdot I$ \\
\hline 25 & 6 & 7 & 4 & $6 \cdot 4$ & I & 4.9 \\
\hline $\begin{array}{l}50 \\
70\end{array}$ & $\begin{array}{l}0,9 \\
12\end{array}$ & 4,0 & 3 & $7 \cdot 2,5 \cdot 1$ & 3,2 & $3 \cdot 6$ \\
\hline 90 & - & - & - & $0.5,0,0.2$ & - & $5 \cdot 7^{\star}$ \\
\hline 95 & - & $\star \overline{\text { Excluc }}$ & - & ; see below & $I \cdot I, 0.7)$ & \\
\hline
\end{tabular}

Particulate ferric phosphate, like total iron, may possibly be greatest in bottom water. Similar but less clear-cut deductions may be drawn from other stations worked in January 1947.

For station $\mathrm{X}_{4}$ evidence has already been produced (p. 287) that the very low reducible and total iron in the bottom-most layer of water $(90 \mathrm{~m}$.) might be attributed to removal of particulate iron by bottom-dwelling animals, such as the suspension feeding mollusc, Pinna. At the time of analysis the low bottom phosphate, compared with samples from 25 and $50 \mathrm{~m}$., was disconcerting, resulting in triplicate analyses of bottom water made 43,44 and $62 \mathrm{hr}$. after collection. The very close agreement, $37 \cdot 6,37 \cdot 1$ and $37 \cdot 3$ units now suggests that Pinna had done their work well, leaving no particulate phosphate at all in the bottom water. Under the isothermal, isohaline conditions prevailing, 37.3 units appears to be a precise measure of the truly dissolved inorganic phosphate of the water column. If this premise may be accepted, 
the results for station $\mathrm{X}_{4}$ in Table $\mathrm{X}$ represent not the minimal but the actual distribution of particulate ferric phosphate, amounting at $50 \mathrm{~m}$. to as much as 6 units $\left(=0.06 \mathrm{mg} .-\mathrm{mol} . / \mathrm{m}^{3} \mathrm{FePO}_{4}\right)$.

\section{Classification of the Forms of Iron In Sea Water}

The forms of iron which may be present in sea water may be classified as follows:

A. Uniformly dispersed iron

(I) Ionic iron. Cationic iron, $\mathrm{Fe}^{++}, \mathrm{FeOH}^{++}$and $\mathrm{Fe}^{+++}$in true solution in sea water at equilibrium will amount to not more than $10^{-8} \mathrm{mg}$.-atom $/ \mathrm{m} .^{3}$ (Cooper, 1937). Since equilibrium is only slowly attained, somewhat more may exist in sea water in which iron is in process of regeneration and redispersion. Ferrite anion, $\mathrm{H}_{2} \mathrm{FeO}_{3}{ }^{\prime}$, may also perhaps be present in similar amount (Cooper, I948b). Ionic iron is never likely to be detectable by chemical analysis.

(2) Dissolved inorganic complexes. Ferrifluoride is readily hydrolysable by sea water (Cooper, I948b) and no evidence for any other inorganic complexes has yet been produced.

(3) Dissolved crystalloidal or dispersed colloidal organic compounds. Ferricitrate, when added to sea water, proves to be one of the less readily hydrolysed complexes of iron and there is indirect evidence of the existence of citrate in the sea. Crystalline calcium citrate tetrahydrate was dredged by R.R.S. Discovery $I I$ at station $4 \mathrm{I} 7,7 \mathrm{I}^{\circ} 22^{\prime} \mathrm{S}$., $16^{\circ} 34^{\prime} \mathrm{W}$. in $2580 \mathrm{~m}$. and appears quite definitely to have been formed in situ (Bannister \& Hey, I936). The bottom water of the Weddell Sea therefore contains sufficient citrate-ion to exceed the solubility product of calcium citrate. Ferricitrate may therefore exist in natural sea water. Breakdown products of haemoglobin and cytochrome such as haematin are also likely. Haemoglobin and haematin have both been found to be unusable as sources of iron by diatoms (Harvey, I945, p. 35). The iron found in filtered deep ocean water by Rakestraw et al. (I936) and Thompson \& Bremner (1935b) may well be attributable to organic iron which may or may not be directly assimilable by plants.

(4) Colloidal inorganic compounds such as ferric hydroxide or phosphate held in a dispersed sol by mucilaginous or other organic 'protective' colloids. Harvey $(1937 b)$ has shown that hydroxylic substances impart considerable protection to ferric hydroxide sols which often then become electronegative. Given time enough they all hydrolyse and ferric hydroxide precipitates.

\section{B. Aggregated or particulate iron}

(I) Discrete flocculent particles of ferric hydroxide or phosphate. There is good evidence for the existence of both in sea water (Harvey, I937 $a, b$ ).

(2) A unimicellar film of ferric hydroxide, electropositive and unprotected by organic colloids, covering a considerable part of the sea surface. 
(3) Ferric hydroxide or phosphate adsorbed upon the surface of organic or inorganic detritus, upon living diatoms (Harvey, I937a) or upon other phytoplankton.

(4) Iron in faecal pellets. The particulate ferric phosphate indicated by analysis is likely to be associated with, or to arise from, faecal pellets (see Cooper, I $948 b$ ). Since the gut of many marine animals is considerably more acid than sea water, iron and phosphate there meet under conditions well suited to the formation and precipitation of ferric phosphate. There also ferric hydroxide and phosphate will receive 'protection' from slime and mucilage. It remains to be seen what happens to iron when bacteria break down excreta, returning the more soluble components to the water.

These four fractions must together be mostly responsible for the 'coarsely particulate reducible' fraction amounting at midwinter to $0.19 \pm$ (S.D.) $0.12 \mathrm{mg}$.-atom $/ \mathrm{m}^{3}$ in the 0 to $50 \mathrm{~m}$. layers. In summer water at least, much of this particulate reducible iron is soluble at $\mathrm{pH} 4$. Many of the particles must be large, $\mathrm{IO0} \mu$ or more in diameter.

(5) Organically bound iron in the cells and tissues of living and dead plants and animals. With this fraction and perhaps with faecal pellets also may be identified the 'very coarsely particulate unreducible fraction' found in the bottom water, there amounting to about $0.32 \pm$ (s.D.) $0.36 \mathrm{mg}$.-atom $/ \mathrm{m} .{ }^{3}$. There must be some such iron in the upper waters also.

(6) Terrigeneous iron in clay and suspended mineral matter derived from the land. Such, in general, will not be determinable by the methods employed here though they will figure in analyses by the methods of T. G. Thompson and his collaborators.

\section{Possible Lines of Advance}

Assessment of the distribution of iron and of a plankton population by examination of small samples of water suffer from similar drawbacks. Only very large numbers of samples can overcome the great variability due to swarming or concentration in some places and not in others of plants, animals and their excretory products. Further analyses of sea water for iron by existing methods do not therefore offer the most promising line of advance.

Single particles-diatoms, faecal pellets, organic and inorganic detritusneed to be examined by microscopic and microchemical techniques to assess the nature of the particulate distribution of iron. The particles in the bottom layers and their interchange with the upper layers especially need attention. The adsorption and assimilation of iron by diatoms, centric and pennate, flagellates and other planktonic algae demands further knowledge. Do the plants gather all the available inorganic iron to themselves leaving none for later generations except that arising from their own death? Must forms of iron other than hydroxide and phosphate first be hydrolysed? What is the function 
of iron in auxospore formation and expansion? Are any organisms favoured by the concentration of iron and possibly ammonia (Cooper, I948 a) in the surface film? In what form is the iron in animal faeces and how quickly is this iron made available to plants? Again, do extensive beds of bottom-dwelling suspension feeders immobilize sufficient iron to affect the productivity of the overlying water?

\section{SUMMARY}

With 2:2'-dipyridyl as reagent for reducible and total iron, determinations were made on samples from the western English Channel at midwinter 1946-47, at the time of the maximum of phosphate, and also in July 1936.

The midwinter results have been treated statistically and the errors of analysis assessed.

Unlike phosphate and nitrate, much of the inorganic iron occurs as particles of fair size, distributed at random in the water. In winter there is no statistically significant difference between the total iron content of samples drawn from $0.5,5,25$ and $50 \mathrm{~m}$. depth, the grand mean and standard deviation for the whole area being $0.25 \pm 0 . \mathrm{II} \mathrm{mg}$.-atom $/ \mathrm{m}{ }^{3}$. The reducible iron for the same depth range and area was $0 \cdot 19 \pm 0.14 \mathrm{mg}$.-atom $/ \mathrm{m}^{3}$. There appears to be about $0.06 \mathrm{mg}$.-atom $/ \mathrm{m}^{3}$ of iron which is reasonably highly dispersed and not determinable until the water has been oxidized with bromine.

In the bottom layers of water, although the reducible fraction differs little from the overlying layers, the total iron shows a very much greater mean value and variance.

The very low content of total and reducible iron and of particulate ferric phosphate in bottom water at a position $49^{\circ} 30^{\prime} \mathrm{N}$., $5^{\circ} 00^{\prime} \mathrm{W}$. has been provisionally attributed to removal by a dense bed of suspension feeders, possibly the mollusc Pinna.

By a statistical examination of the analytical results it has been deduced that the particulate fraction in the upper $50 \mathrm{~m}$. was distributed on an average amongst about 45 particles per litre, each containing about $0.24 \mu \mathrm{g}$. Fe and with a diameter of about $\mathrm{I} 60 \mu$. This result has been compared with data on the distribution of iron in plankton organisms.

As a statistical average waters richer in phosphate were also richer in total iron, the atomic ratio $\mathrm{Fe} / \mathrm{P}$ being about 0.57 .

In July 1936 the 'elegans' water to the westward was much richer in both phosphate and total iron than the more eastern mixed water containing Sagitta setosa. The results agree well with the conclusions drawn from the cruises at midwinter 1946-47.

In 1933-34 concentration of iron was frequently observed in the surface layers; in 1946-47 it was not. In the earlier work the surface film was always cut and included in the sample, in the later it was not. The probable amount of 
a surface unimicellar film of electropositive unprotected ferric hydroxide has been calculated and agrees well with observation.

Particulate ferric phosphate was found to the extent of about $0.06 \mathrm{mg}$.$\mathrm{mols} / \mathrm{m} .^{3}$ This appears to increase towards the bottom.

The success of the work at Newlyn in January 1947 owes much to the willing co-operation of Capt. Creese and the crew of R.V. Sabella under very adverse weather conditions. To Mr P. G. Corbin grateful thanks are due for undertaking single-handed the supervision of all the scientific work at sea on stations never more than two hours apart for two or three days on end. The statistical development would not have been possible without the unstinted assistance of Mr G. M. Spooner.

\section{APPENDIX I}

\section{Statistical Methods Used and Correction Terms (SEe P. 28I)}

Two correction terms were needed, one for the extinction of light by the colour of ferrous-tris-dipyridyl formed from iron impurities in the reagents and determinable in freshly distilled water, the other for the turbidity or extinction due to scattering and absorption by substances dissolved or suspended in the sea-water samples. These were determined separately and the combined extinctions subtracted from the extinctions observed with the sea-water samples plus reagents. To measure each of these corrections at all accurately taxes the instrument and the observer, and in view of shortage of time four samples only from each cruise were examined for turbidity and the mean value applied as a correction to all analyses made on that cruise. The standard deviations of these mean values were actually less than the values reported on sub-samples of one sample. No error is therefore introduced into the statistical treatment. Later in the year with much more plankton variably distributed this procedure would not have been justified.

Finally in all work flasks, after all-night soaking with chromic cleaning mixture, were left for several hours with slightly acid tap water to leach away adsorbed contaminants from the glass. Flasks were covered with inverted crystallizing dishes except when an operation was in progress. Reagents were added from burettes which also were protected from dust by inverted testtubes.

The large random variations in reducible and total iron discussed in the foregoing paper might reasonably be attributed to a defective method of analysis. That the method is sound for well-dispersed iron is shown by the following experiment. Samples from station E I, $25 \mathrm{~m}$. depth, were brought in on 27 February 1947 in Winchester bottles. Since no membrane filters were available, on 3 March part was filtered under suction through a Whatman No. 544 paper which is hardened, slow filtering and retentive, whilst part was left 
unfiltered. Several series of analyses were carried out in sextuplicate to justify evaluation of the variance and standard deviation. Parallel determinations were made on water drawn from the same station at 5 and $67 \mathrm{~m}$. depth.

Series I. On 5 March, I 1 . of filtered $25 \mathrm{~m}$. water was acidified with $2.5 \mathrm{ml}$. $4 \mathrm{~N}-\mathrm{HCl}$. From this were measured six $\mathrm{I} 50 \mathrm{ml}$. subsamples for determination of reducible iron.

Series 2. As series I but on 5 March $5 \mathrm{I}$ units $\mathrm{Fe}$ as ferric alum were added to the litre of water after filtration and acidification.

Series 3. As series I except that the sea water was unfiltered, the storage Winchesters merely being well shaken.

Series EI, $5 \mathrm{~m}$., unfiltered and Series EI, $67 \mathrm{~m}$., unfiltered. Exactly as Series 3 .

Series reagent blank. Distilled water was treated precisely as Series I but in triplicate only. On each subsample, however, eight drum readings were made instead of four to give the same total number.

Unfiltered turbidity series. Unfiltered water from $25 \mathrm{~m}$. was transferred from the storage Winchester, without treatment other than shaking, to the absorption tube for measurement of colour due to absorption and scattering by constituents of the water.

Filtered turbidity series. Filtered $25 \mathrm{~m}$. water was similarly examined.

Upon all these subsamples, measurements of colour had to be made with the $S_{50}$ filter of the Pulfrich Photometer with the minimum of instrumental and personal bias. All were made on one day, 7 March. There is a slight backlash in the mounting of our Pulfrich eyepiece, spectral filters and drums so that a jolt is always liable to cause a small shift of zero. This source of error is guarded against by a control reading with distilled water (against the distilled water always present in the twin tube) every eighth or tenth determination. No such error arose in this experiment. More serious is the tendency of most observers more or less unconsciously to force subsequent readings on a sample to fall into line with the first. This human weakness is particularly hard to overcome with the highly subjective matching of colours. On 6 March therefore, the arbitrarily numbered flasks of all the above series were placed in random order with the further restriction that no two flasks of the same series were allowed to come next to one another. When colour comparison was made the following day, readings in quadruplicate were entered on a separate sheet in the order in which the flasks presented themselves. The two correction terms which have to be applied are set out in Table XI, where $d$ is the deviation of the observed extinction from the mean. This extinction $(E)$ is the product of an extinction coefficient and the length of the absorption tube in appropriate units, here $25 \mathrm{~cm}$.

The higher turbidity and variance of the filtered compared with the unfiltered water requires comment. On 7 March large numbers of phytoplankton cells were observed in the absorption tubes containing filtered water. Similar 
cells were seen in the water in the last Winchester to be used but not in numbers in any of the other experimental flasks, whether the water had been filtered or not. On 3 March at the start of filtration the paper had not bedded down well in the Buchner funnel and consequently the faulty filtrate was filtered again. Evidently a few cells were left in the filtration flask and were transferred to the first Winchester to be filled and the last to be emptied. There in the next 4 days they must have found conditions favourable for rapid division which were absent in the remaining two Winchesters of filtered water and experimental flasks. Though these Winchesters were for part of their time in a cupboard, sufficient attention was not given to keeping them away from light. The Winchesters of unfiltered water were never removed from their cupboard except when required. The explanation of the very high variance is clear. Since the errant Winchester was supposed to contain homogeneous water it was not shaken very thoroughly before transferring the subsamples to flasks, which therefore, in fact, contained varying amounts of the cell culture causing varying extinction of light to be measured. Unfortunately at the time, the possible significance of the observation for work on cultures was not appreciated so that the species responsible was not identified. None of the other series of measurements with filtered water contained water from this Winchester.

\section{Table XI. Extinctions Required as Correction Terms}

$\begin{array}{cccccc}\begin{array}{c}\text { No. of } \\ \text { sub- } \\ \text { samples }\end{array} & \begin{array}{c}\left(E=\log _{10} I_{0} / I\right) \\ \text { Arithmetic } \\ \text { mean }\end{array} & \begin{array}{c}\text { Average } \\ \text { deviation }\end{array} & \frac{\Sigma d}{n} & \begin{array}{c}\text { Variance } \\ \times 10^{6 \star}\end{array} & \begin{array}{c}\text { Standard } \\ \text { deviation }\end{array} \\ \begin{array}{c}\text { Series } \\ \frac{\Sigma d^{2}}{n-I}\end{array} \\ \text { blank in dist. water } & 3 & 0.0106 & 0.0005 & 0.39 & 0.00062 \\ \text { ty, unfiltered water } & 6 & 0.0288 & 0.0008 & 0.97 & 0.00098 \\ \text { ty, filtered water } & 5 & 0.0318 & 0.0018 & 51.90 & 0.007 \mathrm{I}\end{array}$

Reagent blank in dist. water

Turbidity, unfiltered wate

Turbidity, filtered water

* This and Table XII are the only ones where variance has to be multiplied by $10^{6}$; in all others the units have been chosen to avoid this operation.

In consequence of this, the rather lower and more regular turbidity determination on the unfiltered water has been applied as the correction term for all samples. The accuracy but not the precision of these iron analyses may therefore have been slightly affected. However, this experiment was concerned more with precision than with absolute accuracy. The correction term to be subtracted from the iron determinations is therefore the sum of the first two extinctions in Table XI:

$$
0.0106+0.0288 \pm 10^{-3} \times \sqrt{ }(0.39+0.97)=0.0394 \pm 0.00117 .
$$

The variance was $1 \cdot 357 \times 10^{-6}$.

The extinctions for the series made to determine reducible iron in filtered or unfiltered sea water are set out in Table XII. 
Table XiI. Extinctions for Reducible Iron in the Sea Water Series

$\begin{array}{cccccc}\begin{array}{c}\text { Series } \\ \text { EI, } 25 \mathrm{~m} .\end{array} & \begin{array}{c}\text { No. of } \\ \text { sub- } \\ \text { samples }\end{array} & \begin{array}{c}\text { Arithmetic } \\ \text { mean }\end{array} & \begin{array}{c}\text { Average } \\ \text { deviation }\end{array} & \begin{array}{c}\text { Variance } \\ \times \text { I0 }^{6}\end{array} & \begin{array}{c}\text { Standard } \\ \text { deviation }\end{array} \\ \text { I } & 5 & 0.0012 & 0.005 \mathrm{I} & 40.04 & 0.00633 \\ 2 & 5 & 0.106 \mathrm{I} & 0.0027 & 14.398 & 0.00379 \\ 3 & 6 & 0.0289 & 0.014 \mathrm{I} & 365.48 & 0.019 \mathrm{I} \\ \mathrm{EI}, 5 \mathrm{~m} . & 4 & 0.0152 & 0.0044 & 37.66 & 0.006 \mathrm{I} 4 \\ \mathrm{EI}, 67 \mathrm{~m} . & 4 & 0.0238 & 0.005 \mathrm{I} & 50.6 \mathrm{I} & 0.007 \mathrm{II}\end{array}$

The difference between series $\mathrm{I}$ and 2 showed that an addition of $5 \mathrm{I}$ units $\mathrm{Fe}$ to acidified sea water gave an increment of extinction amounting to $0 \cdot 1049 \pm 0.0074$. The standard deviation is twelve times that in distilled water and is equivalent to 3.8 units Fe. This factor has been used for computing the contents of reducible iron set out in Table XIII.

\section{Table XiII. Reducible Iron IN Water Collected 27. ii. 47}

(mg.-atom $/ \mathrm{m} \cdot{ }^{3} \times$ IOO)

\begin{tabular}{|c|c|}
\hline Series & Abbreviated description \\
\hline$\underset{\mathrm{I}}{\mathrm{E}} \mathrm{i}, 25 \mathrm{~m}$. & Filtered, no added iron \\
\hline 2 & $\begin{array}{l}\text { Filtered and acidified before addition of iron } \\
\text { (510 } \mu \mathrm{g} \text {.-atom) }\end{array}$ \\
\hline 3 & Unfiltered, no added iron \\
\hline $\mathrm{E} \mathrm{I}, 5 \mathrm{~m}$. & Unfiltered, no added iron \\
\hline $\mathrm{I}, 67 \mathrm{~m}$ & Unfiltered, no added iron \\
\hline
\end{tabular}

Reducible iron with standard deviation

$$
\begin{array}{r}
0 \cdot 6 \pm 3 \cdot 08 \\
5 \mathrm{I} \cdot 6 \pm \mathrm{I} \cdot 84 \\
\mathrm{I} 4 \cdot \mathrm{I} \pm 9 \cdot 29 \\
7 \cdot 4 \pm 2 \cdot 98 \\
\mathrm{II} \cdot 6 \pm 3 \cdot 46 \\
\mathrm{II} \cdot 5
\end{array}
$$

Within the limit of error of the method, filtration through Whatman No. 544 filter paper removed all the reducible iron in the water. Providing that the sea water is acidified before the addition of ferric salt the increment in colour is identical with that in distilled water (unpublished work). There is no 'salt error'. Unfiltered sea water from $25 \mathrm{~m}$. therefore contained I4.I units reducible iron, all of which was removable by filtration, whilst at 5 and $67 \mathrm{~m}$. there was somewhat less. Again, the standard deviation on filtered water attributable to analytical error amounted to $3 \cdot I$ units.

Except in considering particle size (pp. 288-9I), no assumption has been made as to the mathematical nature of the statistical distribution other than that variance is an additive property. Clancey (1947) has concluded that many of the distributions met in chemical analysis depart radically from the 'normal' and are possibly to be regarded more correctly as forms of 'rare occurrence' distributions. These have to be combined with distributions, probably of the 'normal' or Poisson type, arising from the interplay of biological and chemical factors in the water. 


\section{APPENDIX II \\ Statistical ANalysis of the 'Total Iron' Data, I946-47, BY G. M. SPOONER, M.A.}

The 'total iron' data presented in Table II have been arranged so that the values for each depth at different stations are grouped; except for the deepest sample at each station, taken less than $20 \mathrm{~m}$. from the bottom. Such samples are separated out as 'bottom' samples.

When this is done it is at once apparent-as indeed is evident from inspection of Table II-that the bottom readings are more variable than those taken well away from the bottom ('upper water layers') and include most of the higher values. By contrast, depths from 0 to $50 \mathrm{~m}$. give more uniform results, both separately and when compared with each other. It is also clear that one station, $\mathrm{A}_{3}$, which had been worked in rough weather, stands apart from the rest, and evidently presents some anomaly: it is excluded from the computations which follow.

The means and variances for the values obtained at different depths are given in Table XIV.

Table XIV. Total Iron at Different Depths

\begin{tabular}{|c|c|c|c|c|c|}
\hline $\begin{array}{l}\text { Depth } \\
\text { (m.) }\end{array}$ & $\begin{array}{c}\text { No. } \\
\text { of } \\
\text { analyses }\end{array}$ & $\begin{array}{l}\text { Mean } \\
\pm \text { S.E. }\end{array}$ & $\begin{array}{c}\text { Sum } \\
\text { of squares }\end{array}$ & $\begin{array}{l}\text { Degrees } \\
\text { of } \\
\text { freedom }\end{array}$ & $\begin{array}{c}\text { Mean square } \\
\text { (variance } \\
\text { estimate) }\end{array}$ \\
\hline
\end{tabular}

Upper water layers (0-50 m.):

\begin{tabular}{|c|c|c|c|c|c|c|}
\hline o & 8 & $23 \cdot 13 \pm 2.83$ & $448 \cdot 9$ & 7 & $64 \cdot 13$ & $8.0 I \pm 2.00$ \\
\hline 5 & I9 & $24.84 \pm 2.55$ & $2098 \cdot 5$ & I8 & II6.59 & $10.80 \pm I .75$ \\
\hline 25 & 22 & $25.64 \pm 2.66$ & $3275 \cdot I$ & $2 I$ & I55.96 & $12.49 \pm 1.89$ \\
\hline 50 & I9 & $25 \cdot 79 \pm 2 \cdot 24$ & I7 I 3.2 & I8 & $95 \cdot \mathrm{I} 8$ & $9 \cdot 76 \pm I \cdot 58$ \\
\hline Total & 68 & $25 \cdot I 6 \pm I \cdot 3 I 6$ & $7535 \cdot 65$ & 64 & II $7 \cdot 74$ & $10.851 \pm 0.9305$ \\
\hline
\end{tabular}

Intermediate water $(60-75 \mathrm{~m}$. below the surface and $23-37 \mathrm{~m}$. above the sea bed):

$$
\begin{array}{cccccc}
8 & 45.6 \pm 6.07 & 2059 \cdot 9 & 7 & 294.27 & \text { I } 7 \cdot \text { I } 5 \pm 4.29
\end{array}
$$

Bottom water:

$23 \quad 50 \cdot 87 \pm 8.03 \quad 32,573.6 \quad 22 \quad 1480.62 \quad 38.48 \pm 5.68$

The following points deserve notice:

(I) The mean value for total iron at the bottom is larger than that in the upper layers. Though the estimate for the bottom is not very precise, it can be said to be roughly twice as great. (2) The variation between analyses at one depth is clearly greater on the bottom, the standard deviation being some 3 to 4.5 times that of analyses from the upper layers. (3) Within the 'upper water layers', analyses from different depths (0, 5, 25, $50 \mathrm{~m}$.) do not show any marked differences, either in mean values, which indeed seem more uniform than might have been expected, or in variation between analyses. This phenomenon will be examined more closely below, but in the meantime it is 
useful to call attention to the values for the total number (68) of analyses for the upper water layers, which are given in heavier type in Table XIV. (4) The few analyses from depths greater than $50 \mathrm{~m}$., but not close to the bottom, here classed as 'intermediate' depths, clearly give results of an intermediate character-that is, intermediate between those from the shallower depths (considered separately or combined) and the bottom.

The figures suggest that close to the bottom there is rather more iron than in the main part of the water column, and that it is more erratically distributed-presumably because part of it there occurs in coarse particulate aggregations which are normally absent from the upper layers. The influence of the bottom is felt some little distance above, but for the area under survey, where depths ranged from 80 to $\mathrm{I} 20 \mathrm{~m}$., it can be said that the top $50 \mathrm{~m}$. at least was free from this influence. Throughout this top $50 \mathrm{~m}$. conditions appear to be comparable.

Attention will now be confined to the 68 analyses from the top $50 \mathrm{~m}$. (Fig. 2, upper part of middle histogram less readings for station $A_{3}$ ), and the variation found amongst them examined in greater detail. These 68 analyses, with a mean of $25 \cdot 16$ units, have a 'Sum of Squares' of $7583 \cdot 2$, giving (for 67 degrees of freedom) a mean square of II3.I8 and S.D. of 10.64 (see foot of page). The latter is relatively high, and indicates that $5 \%$ of the analyses may be expected to lie outside the (approximate) limits of 4 to 47 units. How much of this variation, it must be asked, is due to differences between the several stations at which samples were taken, or to differences between depths? And how far has it been reduced by triplicating the analyses of some of the samples? To attempt an answer, 'analysis of variance' technique must be used.

At the outset it is evident that difficulties may arise through the lack of symmetry of the original data. As has been pointed out (p. 280), circumstances prevented measurements at all depths at every station, while it proved possible to replicate some of the samples, but by no means all. It is thus necessary to proceed with caution in attempting a partition of the variance, and to guard against any bias which might lead to invalid conclusions. As will be seen, however, difficulties largely resolve themselves, owing to the high degree of homogeneity which the data possess. The main object is to arrive at an estimate of the sampling variance when the effects of any differences between depths or between stations have been excluded.

The figures in Table XIV have already indicated that depths down to $50 \mathrm{~m}$. give comparable results. Analysis of the variance shows:

\begin{tabular}{lccc} 
& $\begin{array}{c}\text { Degrees of } \\
\text { freedom }\end{array}$ & $\begin{array}{c}\text { Sum of } \\
\text { squares }\end{array}$ & Mean square \\
Between depths & 3 & 47.57 & I5.9 \\
Within depths & 64 & 7535.65 & II $7 \cdot 74$ \\
Total & 67 & $7583 \cdot 2$ & II 3.18 \\
\multicolumn{2}{c}{ * Sum of the separate items given in Table XIV. }
\end{tabular}


Depth difference has therefore introduced no extra variation, since the value II 7.8 is not less than II3.I8. Indeed the effect shown is all the other way, though for only 3 degrees of freedom the value 15.9 is not quite significantly low even in a strictly orthogonal comparison. By chance the readings from the four depths average out more closely than might have been expected. The result gives a wide margin for any small bias which the lack of symmetry of the data as a whole may have-introduced.

We can therefore in full confidence disregard differences in depth, when considering the upper layers. This fact is most fortunate, as the original data can now be re-arranged ignoring depth, and much of the asymmetry disappears. The main irregularity now lies in the distribution of replicate readings. These, however, gave a consistent form of result whenever they were made, and they can be safely regarded as representative of the whole sample. (An analysis of the samples with which they are concerned is given below.) Analysis may now proceed to separate off the influences of station-diversity and replicate sampling, as follows:

\begin{tabular}{|c|c|c|c|c|}
\hline & $\begin{array}{l}\text { Degrees of } \\
\text { freedom }\end{array}$ & $\begin{array}{l}\text { Sum of } \\
\text { squares }\end{array}$ & $\begin{array}{c}\text { Mean square } \\
\text { (variance) }\end{array}$ & S.D. \\
\hline $\begin{array}{l}\text { Between stations } \\
\text { Between subsamples }\end{array}$ & $\begin{array}{l}\text { I6 } \\
\text { I7 }\end{array}$ & $\begin{array}{l}3933 \cdot 2 \\
\text { IIOI.7 }\end{array}$ & $\begin{array}{r}247 \cdot 8 \\
64 \cdot 8\end{array}$ & $8.05(+\mathrm{I} \cdot 34)$ \\
\hline $\begin{array}{l}\text { Between samples } \\
\text { (within stations) }\end{array}$ & 34 & $2548 \cdot 4$ & $74 \cdot 95$ & \\
\hline Total & 67. & $7583 \cdot 2$ & II 3.18 & $10.64( \pm 0.913)$ \\
\hline
\end{tabular}

The higher variance for the 'between stations' component is significantly different from the other two, and indicates, not surprisingly, that the variability of the analyses has been somewhat increased by taking samples from different places. (Diversity between stations is mainly due to the low-value stations $\mathrm{A}_{4}$ and $\mathrm{A} 6$ and the high-value station $\mathrm{X}_{3}$ : there seems to be little difference between the majority of the stations.)

The variance between the subsamples of those samples for which there are replicate analyses ( 64.8 sq.units) is lower than the other components, though very little less than that of the residual variance ( 74.95 sq.units), thus emphasizing the relative uniformity of the distribution of iron at any given station.

Note. The eight samples for which there is more than one analysis, and which therefore are involved in the 'subsample' data, happen to be quite uniform among themselves, though four different stations are represented. Analysis gives:

$\begin{array}{ccccc} & \begin{array}{c}\text { Degrees of } \\ \text { freedom }\end{array} & \begin{array}{c}\text { Sum of } \\ \text { squares }\end{array} & \text { Mean square } & \text { S.D. } \\ \text { Between subsamples } & \text { I7 } & \text { Iror }: 7 & 64 \cdot 8 & 8 \cdot 05 \\ \text { Between samples } & 7 & 275 \cdot 3 & 39 \cdot 3 & 6 \cdot 27 \\ \text { Total } & 24 & \text { I377.0 } & 57 \cdot 4 & 7 \cdot 57\end{array}$

(The data include twenty-five analyses, made up of three each from samples A r, $5 \mathrm{~m}$.; A r, 25 m.; A 7, 5 m.; A 7, 25 m.; C4, 50 m.; X 4, 25 m.; X 4, 50 m.; and four from X4, 5 m.). 
By eliminating the effects due to the multiplicity of stations and to the occasional subsampling, the variance of 'total iron' analyses is reduced from the first over-all estimate of $\mathrm{II}_{3} \cdot \mathrm{I} 8\left(=\mathrm{I0} \cdot 64^{2}\right)$ to $74^{\cdot 95}\left(=8 \cdot 66^{2}\right)$. This represents a value for the variance which might be found between a number of analyses from the same water-column (down to $50 \mathrm{~m}$.) at any one station. If the analyses are confined to one position in the water-column, i.e. become replicates of a single sample in the sense employed here, the value for the variance will almost necessarily be less than 74.95 , though not necessarily much less. Our direct and independent estimate of this value is 64.8 , the significance of which is thus enhanced.

The 'refined' variance value of 64.8 is important, as it is a measure of the variation which remains between samples which should duplicate each other, and should be virtually identical in chemical composition. It is much larger than any possible variance resulting from errors introduced during the procedure of chemical analysis (see Appendix I). The conclusion reached therefore is that even in the upper water layers the iron is distributed in particulate form. The size of the particles, though less than that of the coarse particles which seem to occur on the bottom (p. 286), must be such that there is quite a small average number in a volume of 150 c.c., and random variations from that number can produce considerable differences in total iron between adjacent bodies of that volume.

From the actual derived value for the variance $(64 \cdot 8)$, the possibility is open for estimating this degree of aggregation of the iron, i.e. of the size and density of the particles with which it is associated, once allowance has been made for the error inherent in the chemical technique used in handling the samples in the laboratory.

\section{APPENDIX III}

\section{Statistical Analysis of the 'Reducible Iron' Data, I946-47}

The data for reducible iron have been examined (Table XV) by the method used for total iron by $\mathrm{Mr}$ Spooner in Appendix II. The number of analyses is considerably less and the conclusions are to that extent less certain. The result at $\mathrm{XI}_{\mathrm{I}}, 75 \mathrm{~m}$. depth (79 units) is omitted.

(I) The results at 5,25 and $50 \mathrm{~m}$. are uniform, indeed more so than might have been expected. There are only three surface $(0.5 \mathrm{~m}$.) results and these are all relatively high $(27,20$ and 53 units). These, standing by themselves, have little significance and there is no good reason for leaving them out of the further statistical analysis. This leads to a mean reducible iron content of the upper layers $(0.5,5,25$ and $50 \mathrm{~m}$.) of 19.3 units.

(2) The mean reducible iron content of the bottom waters was less than in the upper layers though probably not significantly so. The result is in strong contrast with that for total iron. 
(3) The variance and standard deviation was much the same in bottom water as in the upper layers. The number of analyses scarcely justifies a further analysis on the lines of that for total iron.

(4) The difference between the mean values for total and for reducible iron gives a measure of the unreducible fraction which has been worked out for the several standard depths other than the surface (Table XVI). The variance estimate, also found by difference, is sometimes negative. For the upper layers $(5,25$ and $50 \mathrm{~m}$.), the unreducible iron amounts to about 6 units. The ratios of the variances of total and of reducible iron examined in terms of their degrees of freedom suggests that the variance estimate of the unreducible iron does not differ significantly from zero. It is safe to say that the variance

\section{Table XV. Reducible Iron at Different Depths}

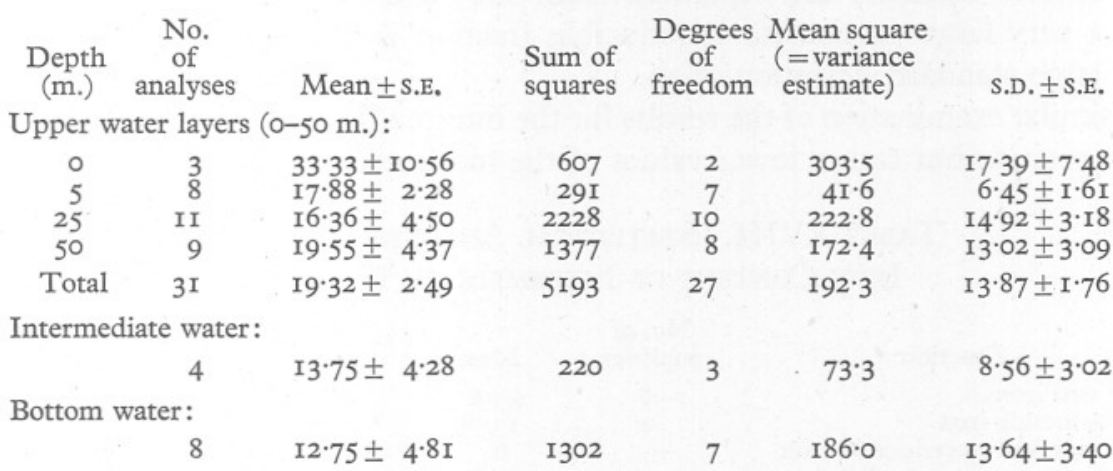

Table XVI. Unreducible Iron at Different Depths as DifFerence between Means for Total and Reducible Iron

\begin{tabular}{|c|c|}
\hline $\begin{array}{l}\text { Depth } \\
\text { (m.) }\end{array}$ & $\begin{array}{l}\text { Difference } \\
\text { of means }\end{array}$ \\
\hline
\end{tabular}

Upper water layers $(0-50 \mathrm{~m}$.$) :$

$\begin{array}{ccc}5 & 6 \cdot 96 & +75 \cdot 0 \\ 25 & 9 \cdot 28 & -66 \cdot 8 \\ 50 & 6 \cdot 24 & -77 \cdot 2 \\ \text { Total } & 5 \cdot 84 & -74 \cdot 6 \\ \text { Intermediate water: } & 3 \mathrm{I} \cdot 8 & +22 \mathrm{I} \cdot 0 \\ \text { Bottom water: } & 38 \cdot \mathrm{I} & +\mathrm{I} 295\end{array}$

estimate of the unreducible iron is negligible or at least quite small compared with that of reducible iron in the upper layers. This fraction (about 6 units) is therefore reasonably uniformly distributed throughout the upper layers. At midwinter with vertical mixing of the water proceeding freely this must be true of the bottom water also. Also the random distribution of total iron in the upper layers is entirely due to the reducible component, i.e. ferric hydroxide 
and phosphate. (These deductions assume that there is no inverse correlation between reducible and unreducible iron. Only further investigation can rule out this unlikely event.)

\section{Table XVII. Statistical Analysis of the IRON CONTENT OF BOTTOM WATER}

\begin{tabular}{lcccc}
\multicolumn{1}{c}{ Fraction } & $\begin{array}{c}\text { No. of } \\
\text { analyses }\end{array}$ & Mean & $\begin{array}{c}\text { Variance } \\
\text { estimate }\end{array}$ & $\begin{array}{c}\text { Standard } \\
\text { deviation }\end{array}$ \\
Total iron & 23 & $50 \cdot 87$ & I480.62 & $38 \cdot 48$ \\
Reducible iron & 8 & I2.75 & I86.0 & I3.64 \\
Dispersed unreducible iron & - & 6 & Approx. zero & Approx. zero \\
Particulate unreducible iron & - & $32 \cdot 1$ & I294.6 & $36 \cdot 0$
\end{tabular}

It will be seen from Table XVII that when the reducible and dispersed unreducible fractions are separated from the total iron in bottom water, that a very large particulate unreducible fraction is left- 32 units with the very large standard deviation of 36 .

A similar examination of the results for the intermediate layer (Table XVIII) gives positive but rather lower values of the mean and standard deviation.

\section{Table XVIII. Statistical Analysis of the IRON CONTENT OF INTERMEDIATE WATER}

\begin{tabular}{lcccc}
\multicolumn{1}{c}{ Fraction } & $\begin{array}{c}\text { No. of } \\
\text { analyses }\end{array}$ & Mean & $\begin{array}{c}\text { Variance } \\
\text { estimate }\end{array}$ & $\begin{array}{c}\text { Standard } \\
\text { deviation }\end{array}$ \\
Total iron & 8 & $45 \cdot 6$ & $294 \cdot 27$ & I7.15 \\
Reducible iron & 4 & 13.75 & $73 \cdot 3$ & $8 \cdot 36$ \\
Dispersed unreducible iron & - & 6 & Approx. zero & Approx. zero \\
Particulate unreducible iron & - & $25 \cdot 85$ & $221 \cdot 0$ & 14.9
\end{tabular}

\section{REFERENCES}

BANNISTER, F. A. \& HeY, M. H., I936. Report on some crystalline components of the Weddell Sea deposits. Discovery Rep., Vol. I3, pp. 60-9.

BucH, K., I942. Analytisk bestämning av extremt låga järnkoncentrationer med $\alpha: \alpha^{\prime}$-dipyridyl. Finska Kemistsamfundets Meddelanden, Nos. I-2, pp. I-I8.

Clancey, V. J., I947. Statistical methods in chemical analysis. Nature, Vol. I59, pp. 339-40.

CONSEIL INTERNATIONAL POUR L'EXPLORATION DE LA MER, I933. Bull. Hydr., pp. 6I-2.

Cooper, L. H. N., I933. Chemical constituents of biological importance in the English Channel, November, I930, to January, I932. Part I. Phosphate, silicate, nitrate, nitrite, ammonia. Fourn. Mar. Biol. Assoc., Vol. I8, pp. 677-728.

- I935. Iron in the sea and in marine plankton. Proc. Roy. Soc., B, Vol. II8, pp. 419-38.

- 1937. Some conditions governing the solubility of iron. Proc. Roy. Soc., B., Vol. I24, pp. 299-307.

_- r948 a. Particulate ammonia in sea water. Fourn. Mar. Biol. Assoc., Vol. 27, pp. 322-6.

I $948 \mathrm{~b}$. Some chemical considerations on the distribution of iron in the sea. fourn. Mar. Biol. Assoc., Vol. 27, pp. 3I4-2I. 
GrAN, H. H., I93I. On the conditions for the production of plankton in the sea. Rapp. Proc.-verb. Cons. int p. l'Expl. Mer, Vol. 75, pp. 37-46.

- I933. Studies on the biology and chemistry of the Gulf of Maine. II. Distribution of phytoplankton in August, 1932. Biol. Bull. Woods Hole, Vol. 64, pp. I59-82.

Harvey, H. W., I937a. The supply of iron to diatoms. Fourn. Mar. Biol. Assoc., Vol. 22, pp. 203-I9.

- I $1937 b$. Note on colloidal ferric hydroxide in sea water. Fourn. Mar. Biol. Assoc., Vol. 22, pp. 221-25.

- I945. Recent Advances in the Chemistry and Biology of Sea Water. Cambridge Univ. Press, pp. I-I64.

Harvey, H. W., Cooper, L. H. N., Lebour, M. V. \& Russell, F. S., I935. Plankton production and its control. fourn. Mar. Biol. Assoc., Vol. 20, pp. 407-42.

Mokrushin, S. G., I947. The surface layers of colloidal solutions and the size of colloidal particles. Trans. Faraday Soc., Vol. 43, pp. I-2.

Rakestraw, N. W., MahnCKe, H. E. \& BeACH, E. F., I936. Determination of iron in sea water. Ind. Eng. Chem. (Anal.), Vol. 8, pp. I36-8.

SeIwell, G. E., I935. Note on iron analyses in Atlantic coastal waters. Ecology, Vol. I6, pp. 663-4.

Thompson, T. G. \& BREMneR, R. W., I935a. The determination of iron in sea water. Fourn. du Cons. int. p. l'Expl. Mer, Vol. ro, pp. 33-8.

I $935 b$. The occurrence of iron in the waters of the north-east Pacific Ocean. Fourn. du Cons. int. p. l'Expl. Mer, Vol. Io, pp. 39-47. 